\author{
Ronald Findlay \\ Kevin H. O’Rourke \\ Working Paper 8579 \\ http://www.nber.org/papers/w8579 \\ NATIONAL BUREAU OF ECONOMIC RESEARCH \\ 1050 Massachusetts Avenue \\ Cambridge, MA 02138 \\ November 2001
}

Revised version of a paper presented at the NBER conference on Globalization in Historical Perspective, Santa Barbara, May 2001. We are grateful to our discussant Doug Irwin, to the editors, and to participants at that conference for useful comments; and to Jeff Williamson for allowing us to draw on previous collaborative work involving him and one of us. The usual disclaimer applies. The views expressed herein are those of the authors and not necessarily those of the National Bureau of Economic Research.

(C) 2001 by Ronald Findlay and Kevin H. O'Rourke. All rights reserved. Short sections of text, not to exceed two paragraphs, may be quoted without explicit permission provided that full credit, including $(\mathrm{C}$ notice, is given to the source. 
Commodity Market Integration, 1500-2000

Ronald Findlay and Kevin H. O'Rourke

NBER Working Paper No. 8579

November 2001

JEL No. F1, N7

\begin{abstract}
This paper provides a summary of what is known about trends in international commodity market integration during the second half of the second millennium. The range of goods which have been traded between continents since the Voyages of Discovery has steadily increased over time, and there has been substantial commodity market integration over the period, driven by technology in the $19^{\text {th }}$ century and politics in the late $20^{\text {th }}$ century. However, this trend towards greater market integration was not monotonic; it was periodically interrupted by shocks such as wars and world depressions, or by endogenous political responses to the distributional effects of globalization itself. In some periods politics has reinforced the effects of technology, while in other periods it has offset them. In several cases, severe shocks have had long-run effects on the international integration of commodity markets, as a result of politically induced hysteresis. Finally, we know remarkably little about international commodity market integration during the $20^{\text {th }}$ century.
\end{abstract}

Ronald Findlay Economics Department Columbia University 420 West 118th Street New York, NY 10027 ref2@columbia.edu
Kevin H. O'Rourke Department of Economics and IIIS Trinity College Dublin

Dublin 2

Ireland and NBER

kevin.orourke@tcd.ie 


\section{Section 1. Introduction}

This paper provides an introduction to what is known about trends in international commodity market integration during the second half of the second millennium. Throughout, our focus is on intercontinental trade, since it is the emergence of large-scale trade between the continents which has especially distinguished the centuries following the voyages of da Gama and Columbus. This is by no means to imply that intra-European or intra-Asian trade was in any sense less significant. It is simply a consequence of the limitations of space.

How should we measure integration? Traditional historians and modern trade economists tend to focus on the volume of trade, documenting the growth of trade along particular routes, or in particular commodities, or trends in total trade, or the ratio of trade to output. While such data are informative, and while we cite such data in this paper, ideally we would like to have data on the prices of identical commodities in separate markets. Commodity market integration implies that these prices should be converging over time; such price convergence will, other things being equal, drive up the volume of trade. However, the volume of trade could also increase for reasons unconnected with integration, or decline for reasons unconnected with disintegration: shifts in supply and demand will also lead to changes in trade flows, and these have no necessary connection with 'globalization'.

Price convergence is thus the best measure of commodity market integration. Price gaps will reflect all relevant costs of doing trade between markets: not just transport costs, but also trade barriers, and those costs associated with wars, monopolies, pirates and so on. For the $19^{\text {th }}$ and $20^{\text {th }}$ centuries trade barriers and transport costs were the most important barriers to trade, and we have fairly detailed accounts of what happened to these, which we provide below. For earlier 
centuries, we have only limited information on these costs, as well on price gaps between markets; in addition, during the mercantilist era price gaps were as likely to be due to trade monopolies, pirates and wars as to transport costs and tariffs, which are more easily quantifiable. Thus, for the earlier period we rely more on qualitative information regarding trade routes, and quantity information regarding the volumes of commodities actually traded; for the later period we are able to switch to more systematic price-based evidence. We begin, however, with a brief description of the preconditions underlying the Voyages of Discovery.

\section{Section 2. World trade before 1500}

Although it has become conventional to see the formation of the world economy as following in the aftermath of the European voyages of discovery in the late fifteenth century this should not be taken to imply that there was no relevant previous history. Columbus and da Gama were both motivated by the incentive to break the monopoly of the spice trade held by the rulers of Egypt and the Italian city-states, particularly Venice and Genoa. Thus we need to have some understanding of the structure and volume of this trade, at the very least. Both China and India, with their large populations relative to Europe, traded with Southeast Asia; and both engaged in the overland trade with Eastern Europe, the Islamic world and the Mediterranean. The Baltic trade was also of significance to both Northern and Eastern Europe. Shipping and nautical technology generally had also emerged through a complex interplay of several civilizations and economic systems.

There is also the question of incentives and capabilities in the determination of 'who discovered whom?' It was once natural to assume that the Europeans were first across the seas 
because they were the first with the necessary technology. This comfortable Eurocentric assumption is belied by the voyages of the Ming admiral Zheng He in the first three decades of the $15^{\text {th }}$ century. This shifts the question from technological capability to economic incentive. Findlay (1996), following Abu-Lughod (1989) and others, provides an outline of a complex pattern of linkages between wool from England and Spain, woolen cloth from Flanders and Italy, furs from Eastern Europe, gold from West Africa, cotton textiles and pepper from India, fine spices such as cloves and nutmeg from Southeast Asia and silk and porcelain from China that existed from at least a thousand years ago. The Islamic world, stretching from the Atlantic to the Himalayas, and Sung China were the most advanced economic systems of that era with large cities, considerable manufacturing production and sophisticated monetary and credit systems. Western Europe, except for the Italian cities and Flanders, was a relatively backward agricultural area.

Despite the destruction unleashed during the process of its creation, the establishment of the Mongol Empire in the $13^{\text {th }}$ century led to a unification of the Eurasian continent as a result of the 'Pax Mongolica' across Central Asia. As Joseph Needham (1954) and others have argued, perhaps without sufficient specificity, the 'Pax Mongolica' led to a significant transmission of ideas and techniques, along with an increased volume of goods and people. In addition, however, there was also the transmission of the deadly plague germs which resulted in the demographic catastrophe of the Black Death in the 1340s: this reduced the population of Europe and the Middle East by about a third. The reduced volume of production and trade led economic historians to speak of the centuries of the Renaissance in Europe as a time of economic depression. As several authors have pointed out, however, the plague raised per capita wealth, 
incomes and wage-rates, replacing a large but relatively stagnant European economy in 1340 that was already at its Malthusian limits with one that had two-thirds of the population but the same amount of land, capital and stock of precious metals in coins and bullion. The economic and monetary consequences of the Black Death are worked out by means of a general equilibrium model with endogenous population, capital and commodity money supply in Findlay and Lundahl (2000). Real wages rise, population slowly recovers driving real wages slowly down again, and an initial inflationary spike is followed by a long phase of deflation. The model postulates a demand for 'Eastern luxuries' that rises with the higher per capita wealth and income, leading to an increased outflow of precious metals to the East and hence a prolonged monetary contraction. Thus what Day (1978) called the 'Great Bullion Famine of the Fifteenth Century' can be explained as a consequence of the Black Death in the previous century. Eventually the model predicts a return to the initial long-run stationary equilibrium that prevailed before the onset of the Black Death, if all underlying behavioral relationships remain unchanged.

As Herlihy (1997) argues, however, the drastically altered circumstances of people's lives would prompt alternatives in attitudes and institutions. The greater scarcity of labor would tend to dissolve feudal ties and stimulate labor-saving innovations, the higher per capita incomes could lead to postponement of the age at marriage in an effort to maintain the higher income levels, and so on. Furthermore, this period of increased incomes and a higher demand for Asian luxury goods coincided with the demise of the 'Pax Mongolica' and its associated overland trade, and a consequent reliance (once more) on traditional Indian ocean trade routes, and monopolistic Egyptian and Venetian intermediaries. Presumably this increased the incentive to find a sea route to Asia. The result of all these changed incentives could well be a more 'modern' society in 1450 
than in 1350 , one which was ready to venture more readily and further abroad and so usher in a true era of globalization with the voyages of discovery linking all the continents by sea.

\section{Section 3. World trade 1500-1780}

\section{Section 3.1. Introduction}

This period opens with the European "Voyages of Discovery" across the Atlantic and around the Cape of Good Hope to the eastern seas, shortly followed by the crossing of the Pacific and the circumnavigation of the globe. The "globalization" of the world economy in the sense of the linking of markets in the Old and New Worlds that had hitherto been separated thus begins in this period, even if we have to wait until later for evidence of a "big bang" in terms of convergence in world product and factor prices. Thus Flynn and Giraldez (1995) are not necessarily only tongue in cheek when they date the "origin of world trade" to the year 1571 when the city of Manila was founded, directly linking the trade of Europe, Asia, Africa and the Americas. However, with transport costs still high relative to production costs, long-distance trade was largely confined to commodities with a high ratio of value to weight and bulk, such as spices, silk, silver and, last but not least, slaves. Nevertheless, the channels were laid along which the volume of world trade could grow later under the influence of technological change, capital accumulation and population growth.

The most momentous immediate consequence of the discoveries was the injection of large amounts of silver into the circuits of world trade, with the influx into Europe in particular leading to the so-called "Price Revolution of the Sixteenth Century". Within Europe the period was marked also by shifts in the locus of what Kindleberger (1996) calls "economic primacy". 
The Iberian voyages led to a shift away from the earlier commercial dominance of Venice and the Italian cities, since the Cape route broke the monopoly shared by Venice and the rulers of Egypt on the spice trade through the Red Sea. The Portuguese were soon displaced however by the rising power of the Dutch, with Amsterdam, the "Venice of the North", displacing the original one and its successor Antwerp. There followed the long struggle between the Dutch and the English East India Companies, the "multinational corporations" of that area.

Despite the prominence of European explorers, conquistadors and merchants during the earlier part of this period it is a profound historical mistake to imagine European dominance of the global economy as dating from soon after the original voyages. Ironically, the phrase "Vasco da Gama Epoch" was coined not by a European but by the nationalist Indian diplomat and historian K. M. Panikkar (1953). We must not forget that Constantinople fell to the Ottoman Turks shortly before da Gama was born and that the Safavids and Mughals established their rule in Persia and India before his death in the first case and shortly after it in the second. All three of these formidable "gunpowder empires" were involved in the network of world trade despite being essentially territorial powers, with dependence on imports of silver for their coinage being the most important link. Access to firearms and opportunities for greater revenue through taxing trade were also an important factor in strengthening native kingdoms throughout Southeast Asia as well as Japan. In the case of Ming China the introduction of the sweet potato, peanuts and other New World crops led to a substantial increase in agricultural productivity, stimulating population growth and the demand for imported silver and leading in turn to the export of tea, porcelain and silk (Ho 1959). 


\section{Section 3.2. Trade after the Voyages of Discovery: qualitative trends}

One way of thinking about the qualitative evolution of world trade over time is given in Mauro (1961), who presents an intriguing intercontinental matrix for world trade during this period, with the Americas separated into Tropical and Temperate Zones. The Voyages of Discovery, as well as those of Captain Cook, led to the emergence of trade flows between continents where previously there had been none; thus cells in the matrix which had been empty were no longer so. Second, once this had happened the range of goods being traded between continents began to expand, in response to declining transport costs, or shifts in demand and supply in the various regions of the world. The period from 1500 to 1780 was marked by a gradual evolution in the type of goods being traded. Originally the goods concerned were for the most part 'non-competing', in the sense that the trade was driven by the availability of commodities in some continents but not in others. Thus, Asia exported spices and silk, while the Americas exported silver. These goods had an extremely high value to bulk ratio, the high prices being due to the absence of local substitutes in destination markets. As the period progressed, bulkier commodities began to be shipped. Typically, these commodities were still only produced in particular continents (e.g. sugar and raw cotton), and only faced rather imperfect substitutes in destination markets (e.g. honey and wool). The great counter-example was India's exports of cotton textiles, which accounted for more than half of the East India Company's exports to Europe in the 1750s (Table 1). However, it was really only after the transport revolutions of the $19^{\text {th }}$ century that inter-continental trade began in homogenous bulk commodities which could be produced anywhere, such as wheat, iron and steel.

The discovery of the Cape route had an almost immediate impact on Venetian imports of 
pepper and spices, but the effect was short-lived. Wake (1979, p.373) reports that pepper imports declined by $85 \%$ in 1501 over the average of the 1490 's and spices by $42 \%$. Portuguese imports supplied half the European market in 1503-06 and much more a decade later (Wake 1979, p.381). However, the Portuguese never succeeded in their ambition to monopolize the pepper and spice trade. As the $16^{\text {th }}$ century progressed the Venetians and the overland trade fought back: in 1560 Venice imported 2000 tons of pepper, more than it had imported in 1496 (Bulbeck et al. 1998, Table 3.2, pp. 72-3). ${ }^{1}$ Nor did the Voyages of Discovery lead to an immediate collapse in European pepper prices: instead, Figure 1 shows real pepper prices initially rising sharply, as the Portuguese disrupted traditional trade routes, and then rising for a second time in mid-century. ${ }^{2}$ They then started to decline, especially during the $17^{\text {th }}$ century, which saw the Portuguese displaced by the Dutch and English East India Companies. Imports into Europe increased substantially and prices fell to $30-40 \%$ below the prices maintained by the Portuguese in the previous century (Wake 1979, p. 389). While Venice had successfully competed with the Portuguese during the $16^{\text {th }}$ century it could not survive the Anglo-Dutch competition in the first half of the $17^{\text {th }}$ century. The annual consumption of pepper in Europe increased from about 3.4 million lbs. in 1611 to 8.6 million lbs. in 1688, of which the Dutch supplied 4.00 and the English 3.24 million lbs, (Wake 1979, p.391).

\footnotetext{
${ }^{1}$ Similarly, the new sea routes did not lead to the collapse of the traditional caravan trade across central Asia. To be sure, this trade did indeed eventually collapse in the late $16^{\text {th }}$ and $17^{\text {th }}$ centuries, but this was primarily due to political turmoil along the route. By contrast, caravan trade did prosper in the late $17^{\text {th }}$ and $18^{\text {th }}$ centuries along a northern route (through southern Siberia and northern central Asia). This trade was conducted by Russian merchants and took place within Russian territory until the merchants reached China itself (Rossabi 1990).

${ }^{2}$ These are the European pepper price series given in Bulbeck et al. 1998, p. 70, deflated by the average Valencian price level calculated in Hamilton (1934).
} 
Pepper production and exports from Southeast Asia rose in response to the increased demand not only from Europe but also from China. Bulbeck et al. (1998, Table 3.7) indicate total exports from Southeast Asia increasing by a factor of 3.4 from the beginning to the end of the $16^{\text {th }}$ century, by a further $50 \%$ to the end of the $17^{\text {th }}$ century and by $20 \%$ more to the end of the $18^{\text {th }}$ century, about sixfold from 1500-1800. The table also shows that the shares of Europe, China and "Other Regions" in total exports were stable at roughly one-third each over the entire period, despite considerable fluctuations between decades. Chinese emigrants from the southern provinces engaged in a vigorous expansion of cultivation in Southeast Asia during the $18^{\text {th }}$ century, using innovative labor-intensive methods that raised yields per acre substantially.

Table 1 presents various estimates of the commodity composition of European imports between 1513 and 1780. European imports from Asia were initially dominated by pepper and other spices (nutmeg, mace, cloves and cinnamon), but over time the list of commodities being traded widened. Pepper, which accounted for well over half of imports from Asia in the sixteenth century (and which had initially accounted for more than $80 \%$ of Portuguese imports: Table 1 , Panel A) declined sharply to less than $10 \%$ of Asian imports by the eighteenth. The Portuguese were importing textiles from Asia by the late $16^{\text {th }}$ century; cotton textiles, mainly from India, made up $70-80 \%$ of British East India Company imports after 1660 and were the single most important import commodity for the Dutch as well after 1700 (Table 1, Panels B, C). Tea and coffee were insignificant until they rose sharply around 1700, constituting a quarter of East India Company sales in Europe by the middle of the century. Despite this diversification, however, the Asian trade was still heavily concentrated in just a few items: pepper, fine spices, cotton textiles, tea and coffee constituted between 80 and $90 \%$ of imports from Asia throughout the period 
(Steensgaard 1995, p. 10).

By the middle of the eighteenth century, total colonial imports by England and the Netherlands combined were valued at 32 million pesos, about equally divided between Asia and the Americas (Table 1, Panel D). Quantification of imports from America is more difficult, since this trade was not dominated by a few large companies for long periods of time, as was the case in Asia (Steensgaard 1995, p. 11). The most important non-monetary import was sugar: total European imports of sugar were 170,000 metric tons by about 1750, ten times the level of the early seventeenth century (Steensgaard 1995, p.12). Sugar accounted for roughly $50 \%$ of Europe's imports from America, with the remainder being evenly divided between tobacco and miscellaneous items.

Initially, however, the most important European import from the New World, in terms of its economic consequences, was silver. Table 2 reproduces the data given in Barrett (1990) on flows of silver from the Americas to Europe and Asia, as well as on European exports of silver. American production rose for every quarter-century over this period, from an annual average of 45 tons in $1501-1525$ to 340 tons in $1601-1625,550$ tons in $1701-1725$ and 940 tons in 17761800. Europe imported almost $90 \%$ of this output in the early $16^{\text {th }}$ century, but the proportion shipped to Europe fell over time, reflecting increased retention within the Americas: the figure hovered between $70 \%$ and $80 \%$ during most of the period. Some part of silver production in the New World was exported by the Acapulco galleons across the Pacific to Manila. However, the annual average flow was around 15 tons for most of the seventeenth and eighteenth centuries. It was thus relatively insignificant compared to the export of American silver through Europe. What happened to the silver which Europe imported? Europe's deficit on imports of 
Indonesian spices, Chinese porcelain, silk and tea and Indian cotton textiles was largely paid for by American silver drained from Spain: exports from Europe rose from 100 tons in 1601-1625 to nearly double a century later, after which they flattened out. Calculations by Steensgaard (1995, Table 2) clearly show that the Asian trade of the English and Dutch East India Companies would have been impossible without access to the bullion supplies of the New World to finance the gap between the invoice value of imports and exports of goods and services (the value of remittances). ${ }^{3}$ On the other hand, retention within Europe also rose, from 145 tons in 1601-1625 to 225 tons in 1701-1725 and over 400 tons in the last quarter of the eighteenth century. Indeed, Europe absorbed an increasing proportion of the American shipments over the period (from around $60 \%$ at the start of the $17^{\text {th }}$ century to almost $70 \%$ at the end of the $18^{\text {th }}$ ) despite the widespread allegation that China and India had a supposedly irrational desire to "hoard" specie unproductively. Since bullion formed the "high-powered" money of the period these figures indicate the extent of monetization in Europe and Asia. The impact on Europe of this monetary expansion continues to be a hotly debated issue, and its possible ramifications as far afield as Ottoman Turkey, Mughal India and Ming China have also been examined. Despite its turbulence,

3 Steensgaard presents a calculation of the values of exports, imports and profits of the two East India Companies, expressed as annual averages for the 1740-45 period. Total exports were 6.1 million pesos, while the sales value of imports was 12.8 million pesos, compared with an invoice value of 5.7 million pesos, leaving a gross profit of 7.1 million pesos. Dividends were 1.3 million with 5.8 million left over to cover all costs other than the invoice value of imports. The exports of 6.1 million pesos break down into only 1.2 million for commodity exports while exports of treasure (mainly silver) were over half the total at 3.6 million, the rest being remittances by merchants and staff of 1.2 million, or $20 \%$ of the total. The gross profit margin (ratio to invoice value of sales) was huge at over $125 \%$, roughly the same for both companies, while net profits were estimated by Steensgaard at about 13\% for the English and 10\% for the Dutch company. These net profit figures indicate that the companies were not in any way exceptionally profitable, contrary to the implication by Wallerstein (1980), for example, that vast profits were extracted by the "core" from the "periphery". 
the sixteenth century was almost everywhere an age of monetary, economic and demographic expansion, while the seventeenth has been associated with a famous "Crisis", first identified by Hobsbawm (1954), during which growth stagnated and prices fell. Here again the phenomenon was first debated in a European context but was later extended to the global stage, as in Parker and Smith (1978) and later work.

Another important source of silver, and also copper, in this period was Japan. Everyone is familiar with the idea of a secluded island forced open to world commerce by Commodore Perry in 1853; but there was a period (roughly from 1560 to 1640) when Japan was actively involved in world trade, both directly and indirectly, during which Portuguese and Dutch contacts played a major intermediary role between Japan on the one hand and China and Southeast Asia on the other. Silver exports to China and Southeast Asia were made through the Ryukyu Islands and also through the Dutch East India Company in exchange for Chinese silk and other products. The Company in turn used the silver thus obtained for the purchase of pepper and spices in the Indonesian archipelago, and for cotton textiles in India for eventual shipment to Europe. Barrett (1990, Table 7.4, p. 246) reports that Japan exported an average of between 34 and 49 tons per year to China between 1560 and 1599, and between 150 and 187 tons per year between 1600 and 1640.

Portugal first obtained a lucrative foothold in Japan when the Ming in 1557 banned trade with Japan because of the depredations of Japanese pirates along the southern coasts. Japanese merchants were eager to maintain supplies of raw and woven silk and other Chinese and Southeast Asian products, which they attempted to obtain from Chinese sources through Formosa, the Philippines and Indo-China. With Chinese merchants and emigrants established in 
Southeast Asian ports the Ming ban on trade with China was effectively circumvented. The Portuguese took the opportunity to purchase large quantities of silk and other products at their base in Macau, with silver from the Americas, which they then exchanged in Japan for silver at better prices, in effect profiting by arbitraging the silk-silver price differential between China and Japan at a rate of $70-80 \%$ according to Iwao $(1976$, p.6)

The unification of the country in the second half of the sixteenth century by the great warlord Hideyoshi after a century of civil war led to a boom in economic activity. In particular the output of Japanese silver mines increased greatly because of a new smelting technology introduced by Korean miners in western Japan. Large amounts of silver came to be exported in return for greatly expanded imports of raw silk, which jumped fourfold according to Iwao (1976, p.4). Hideyoshi maintained a privileged position for himself in the regulated trade with the Portuguese and the Spanish, having first claim on all the imports that they brought into the country. Lead ingots for ammunition was an important imported item, with firearms copied from Portuguese models being produced on the island of Tanegashima. After 1600 the new Tokugawa shogun continued the policy of regulated trade through the port of Nagasaki. At the same time the Tokugawa permitted licensed ships, the so-called "vermilion-seal" ships, to trade with Southeast Asia, effectively reducing the monopoly power of the Portuguese in raw silk imports. Iwao (1976, p.10) states that in all about 350 of these ships left Japan in the thirty-year period between the inception and cessation of the policy around 1640. Again the main commodity exported was silver in return mostly for raw silk but other products such as deerskins as well. Iwao (1976, p.10) claims that Japan exported 130-160 thousand kilograms of silver over the period $1615-1625$, or as much as 30 to 40 per cent of world silver production outside Japan. The 
ships that carried the silver were Japanese, Chinese, Dutch and Portuguese.

The Dutch enjoyed a complete monopoly of Western trade with Japan after 1640, since they were able to persuade the Shogun that the Catholic powers were intent on subverting his regime through proselytization by the Jesuits. The Japanese silver influx to Batavia between 1630 and 1680 was at least a third of the total inflow to the company from all sources according to de Vries and van der Woude (1997, Table 9.5). The Japanese bonanza increased the total trade revenue and net surplus over expenses very much over the 1630-1650 period, (ibid., Table 9.4), and raised the profit rate for the company from its inception to 1650 to as high as $27 \%$ per annum (ibid., p. 396).

Japanese silver production and exports both declined during the close of the $17^{\text {th }}$ century as the seclusion policy of the Tokugawa took hold. China continued to obtain silver through imports but now the source was increasingly from the Americas through Manila (von Glahn 1996, Table 5).

\section{Section 3.3. Government policy}

The role of government policy in relation to trade during the $1500-1780$ period was a very active one. Its character, however, was very different from what we have become familiar with in more recent times. Tariff policy for protective purposes, which we assume today to be the standard form of trade intervention, was not then of major importance. According to Davis (1966, p.306), customs duties revealed 'the influence neither of economists' theories nor of ministers' long-term commercial policies, but simply of urgent fiscal needs". Many high customs duties were on non-competing imports such as tea, for example, giving rise to lucrative 
opportunities for smuggling. More ambitious interventions, such as the ill-fated 'Cockayne project' to convert exports of raw wool into woollen cloth to increase domestic value-added and employment, succeeded only in disrupting trade before they were abandoned.

Government policy during this 'Age of Mercantilism' was geared to the active promotion of positive trade balances by the establishment of chartered monopolies, and by the acquisition of overseas colonies as sources of raw materials and profitable re-exports, and as markets for manufactures from the mother country. As Wilson (1949) and others have convincingly argued the emphasis on obtaining specie was not irrational if it provided the means for obtaining strategic imports such as naval stores from the Baltic, and Oriental wares such as tea and muslin for re-export to other European markets. In a classic formulation, Viner (1948) pointed out that the 'power' of the state (primarily naval) was used to obtain 'plenty' through trade, which could be taxed in turn to finance the sources of power. The history of the AngloDutch wars of the seventeenth century and the Anglo-French wars of the eighteenth illustrate the links between commercial and geopolitical factors exemplified by Viner's analysis.

The wars on the continent of Europe involving France, Prussia and Austria were over territorial acquisition and dynastic aggrandizement. These became intertwined however with commercial conflicts in the New World and India, leading some to speak of the Seven Years War from 1756-1763 as the first 'world' war. The bonanza opened up by the Iberian voyages of discovery led to a series of sustained conflicts between their predatory successors that was not to be resolved until the triumph of Britain at the end of the Napoleonic Wars. It is only within a framework such as this that we can obtain a proper perspective on the plethora of monopoly rights, navigation acts, bounties, drawbacks, prohibitions and blockades that constituted trade 
policy during the Age of Mercantilism. Needless to say such an attempt, fascinating as it would be, is well beyond the scope of this paper.

\section{Section 3.4. Trade after the Voyages of Discovery: quantitative trends}

O'Rourke and Williamson (2001, Table 1) assemble an extensive range of published estimates for particular channels of trade for the past five centuries, and compute growth rates of world trade for each of them. The results show that intercontinental trade grew at $1.26 \%$ per annum in the $16^{\text {th }}$ century, and that growth fell to $0.66 \%$ per annum in the $17^{\text {th }}$ century before rising back to $1.26 \%$ per annum in the $18^{\text {th }}$ century. The growth rate for the entire $1500-1800$ period was $1.06 \%$ per annum. Though this may look small to modern eyes it was certainly well ahead of the growth rate of world population during this period, which increased from 461 million in 1500 to 954 million in 1800 , or at a rate of $0.24 \%$ per annum. While we do not have data it is highly unlikely that intercontinental trade as a whole grew faster than world population for any previous century; in this sense, the post-1500 period does mark a clear break with the past. Similarly, the qualitative evidence assembled above regarding the development of new trade routes, especially across the Atlantic, the growing volume of trade in particular commodities over those routes, and changing patterns of comparative advantage, also suggests that 1500 marked an important turning point in the history of world trade.

Nonetheless, the best measure of international commodity market integration remains international price convergence. Figure 2 plots markups for cloves, pepper and coffee (O'Rourke and Williamson 2000, based on Bulbeck, Reid, Tan and Wu 1998), where markups are defined as the ratio of European to Asian price. The figure shows price convergence for cloves from the 
1590 s to the 1640 s, but it was short-lived, since the spread rose to a 350 -year high in the 1660 s, maintaining that high level during the VOC monopoly and up to the 1770 s. The clove price spread fell steeply at the end of the French Wars, and by the 1820 s was one-fourteenth of the 1730s level. This low spread was maintained across the $19^{\text {th }}$ century. Between the 1620 s and the 1730s the pepper price spread remained fairly stable, after which it soared to a 250 -year high in the $1790 \mathrm{~s}$. By the $1820 \mathrm{~s}$, the pepper price spread of the early $17^{\text {th }}$ century was recovered, and price convergence continued up to the 1880 s, when the series ends. While there was some modest price convergence for coffee during the half century between the 1730 s and the 1780 s, the French Wars saw a dramatic rise in price spreads. At the war's end, price convergence resumed, so that the coffee price spread in the 1850 s was one-sixth of what it had been in the $1750 \mathrm{~s}$, and in the 1930s it was one-thirteenth of what it had been in the 1730s. Thus, there is absolutely no evidence of commodity price convergence for these important Dutch imports prior to the $19^{\text {th }}$ century. Was English trade in Asia any different than Dutch trade? Apparently not. Figure 3 plots the average prices received by the East India Company on its Asian textile sales in Europe, divided by the average prices it paid for those textiles in Asia. Again, there is no sign of declining mark-ups (where mark-ups include all trade costs, as well as any East India Company monopoly profits) over the century between 1664 and 1769. Figure 5 in O'Rourke and Williamson (2000) reproduces Chaudhuri's mark-up figures for the East India Company's trade in pepper, saltpeter, tea, raw silk, coffee, and indigo, between about 1660 and 1710 . With the possible exception of saltpeter, it would be very hard to establish a convincing case that markups were declining during this fifty-year period.

Of course, these price spread were not driven solely, or even mainly, by the costs of 
shipping, but rather, and most importantly, by monopoly, international conflict, and government tariff and non-tariff restrictions. For example, for pepper the mark-up in Figure 2 was relatively stable at between three and six over the entire period, reflecting relatively competitive conditions in the pepper market. Where the Dutch were able to secure a monopoly, as with the cloves of the Spice Islands and the cinnamon of Ceylon, this ratio could become enormous, reaching 25 around 1640 for cloves and remaining at about 15 for the next century. ${ }^{4}$ Nonetheless, anything that impedes price convergence suppresses trade, and there is no evidence of secular, intercontinental commodity price convergence before the 1820 s. Nor have scholars such as Menard (1991) uncovered much evidence of transport revolutions during this period (O'Rourke and Williamson 2000). What then drove the unprecedented growth in world trade in the three centuries following Columbus? Outward shifts in export supply and import demand, is the answer suggested by O'Rourke and Williamson (2001), who estimate that between 50\% and 65\% of the boom could have been due to European income growth alone.

\section{Section 3.5. The economic impact of world trade: economic primacy within Europe}

Economic geography models typically ask what the impact of international integration is on the relative welfare of core and periphery. One of the most notable features of this period of globalization, however, was a change in the location of the core itself; and such changes were intimately linked with the changing nature of international trade. In the case of Western Europe

\footnotetext{
${ }^{4}$ The competition in the $17^{\text {th }}$ century between the two great rival companies has been elegantly analysed in terms of the Brander-Spencer duopoly model of strategic trade policy by Irwin (1991). He demonstrates the advantage of the Dutch institutional form in which the decision-makers obtained not only a share of the profit but also of gross revenue.
} 
the Discoveries were said to have induced a shift in the main locus of economic activity from the Mediterranean to the Atlantic, as exemplified by the rise of Antwerp, Amsterdam, Seville, Lisbon and London relative to Venice and Genoa. This makes one think of intercontinental trade as displacing intra-European trade, and therefore illustrating a dramatic early instance of the importance of "globalization". This claim is disputed, however: according to Rapp (1975), "it was the invasion of the Mediterranean, not the exploitation of the Atlantic, that produced the Golden Ages of Amsterdam and London”. Production and marketing innovations in English woolen textiles and Dutch improvements in shipping, as well as a growing dependence of southern Europe on northern grain imports were important factors in shifting "economic primacy" away from the south to Holland and England before the trade with Asia and the New World grew sufficiently in importance. In the 1660s almost half of London's total exports were to the Mediterranean, compared with only $9 \%$ to the Americas and $6 \%$ to Asia (Davis 1962). ${ }^{5}$

The discoveries can be looked upon as creating the prospect for a "new global economy", displacing traditional trade routes and centers. As with the "new economy" of today it was not clear who the eventual "winners" were to be. The Portuguese were the pioneers and Spain controlled the territories in the New World but neither of the Iberian states had the commercial and organizational capacity to fully exploit the opportunities that were opened up. Thus Portugal found it necessary from as early as 1501 to use Antwerp as the emporium through which she would dispose of the spices obtained from the East. Antwerp also attracted the woolen cloth of England, silver, copper and financial capital from South Germany and many other items of

\footnotetext{
${ }^{5}$ Subsequently, however, intercontinental trade grew in absolute and relative importance. The share of colonial commodities in the total imports of London rose from practically nil in 1600 to $24 \%$ in 1660 and to $46 \%$ of total English imports in 1750 .
} 
European and colonial trade. The city grew rapidly in population to over 100,000 by the $1560 \mathrm{~s}$ and could rightly be considered the first truly global emporium, with a range and diversity of commodities vastly exceeding that of Venice, Bruges and other earlier commercial centers. Despite its wealth and splendor, however, Israel (1989) argues that Antwerp was too passive to be a truly dynamic center of world trade, with no active involvement in creating and attracting business towards itself. Its dominance did not last long and the peak was passed before it succumbed to the depredations of the Spanish armies in the last quarter of the sixteenth century. Her entrepreneurs and skilled craftsmen mostly fled to the United Provinces, benefitting the rival that was to supplant her, Amsterdam.

The Dutch "golden age" is usually taken to begin from about 1590 and lasted until about 1740, with a peak in the second half of the seventeenth century. Maddison (1991, p.31) states that Dutch income per head in 1700 was around 50\% higher than in Britain, with the shares of industry and services in total employment substantially higher. He also cites Gregory King as estimating the Dutch savings rate to be $11 \%$ in 1688 as compared with $4 \%$ for Britain and France. The volume of international trade was approximately the same as in Britain, which meant that it was five times as high per capita. How a country whose population never exceeded two million during these years could have led the world economy for so long has been a never-ending source of wonder and controversy among historians down to the present day. Geography provides part of the answer: the foundations were laid by taking advantage of location, midway between the Bay of Biscay and the Baltic. Seville and Lisbon and the Baltic ports were too far apart for direct trade between the two terminal points, enabling the Dutch to provide profitable intermediation, carrying salt, wine and cloth and later silver, spices and colonial products 
eastwards while bringing Baltic grains, fish and naval stores to the west. The Dutch share of European shipping tonnage was enormous, well over half during most of the period of their ascendancy. With such a small population this concentration on trade, shipping and manufacture required reliance on imported grain, most of which was from the Baltic regions. The urban population was over half of the total, with the fifty-seven cities of the seven United Provinces making it one of the most densely populated parts of Europe. The Calvinistic ethic promoted thrift and education, with the lowest interest rates and the highest literacy rates in Europe. The abundance of capital made it possible to maintain an impressive stock of wealth, embodied not only in the large fleet but in the plentiful stocks of an array of commodities that were used to stabilize prices and take advantage of profit opportunities. The grading, sorting and packaging of goods provided the essential services of a commercial "hub".

In comparison with the larger European states the Dutch offset their inferiority in numbers with a concentration on commerce and finance that the others could not match, distracted as they were by dynastic ambitions and other rivalries. While Amsterdam and Holland were undoubtedly the leaders the other provinces and cities cooperated in their own interest. Unlike Antwerp, which was a dependency of the Habsburgs, Amsterdam and the United Provinces were fiercely independent, carrying on a long and successful military struggle against their erstwhile masters the Habsburgs, while continuing to trade with them to obtain silver and other necessities for the operation of their global commercial system. War and trade were inseparable in the Age of Mercantilism, and the Dutch excelled at both, particularly at sea.

There has been an ongoing historical controversy about the "modernity" of the Dutch Republic in the seventeenth century. Identifying modernity with the Industrial Revolution, 
writers such as Braudel, Hobsbawm and Wallerstein have stressed continuities with past patterns of trade and commercial organization, such as Dutch experience with the bulk trade of the Baltic in the case of Braudel, as opposed to any innovative departures. As against this Israel (1989), de Vries and van der Waude (1997) and Steensgaard (1982) have emphasized the originality of the Dutch in creating new institutions and practices to take advantage of the new opportunities opened up by the prospect of intercontinental trade. Steensgaard (1982) convincingly demonstrates how the fusion of public and private interests in creating a large and growing fund of "permanent, anonymous capital" that internalized protection costs while maintaining a steady annual dividend of $12.5 \%$ made the Dutch East India Company of the seventeenth century a truly revolutionary global organization. De Vries and van der Waude (1997) are also convincing in entitling their splendid work on the Dutch economy from 1500-1815 "The First Modern Economy," since as they say "the harbors of the Republic were in direct and continuous contact with Dutch settlements stretching from New Amsterdam and Curacao in the west to Formosa and Nagasaki in the east, and from Smeerenburg on Spitzbergen in the north to Capetown at the southern tip of Africa" (p.376).

\section{Section 3.6. The economic impact of world trade: trade and the Industrial Revolution}

The Industrial Revolution that got underway in Britain in the late $18^{\text {th }}$ century undoubtedly ushered in a new era in the evolution of the world economy, and confirmed the emergence of Britain as the dominant world economic power. As Wrigley (1988) has emphasized, the use of coal and other fossil fuels radically altered the constraints on the world's energy supplies. Until the $18^{\text {th }}$ century even major technical innovations in Europe and Asia 
raised living standards only temporarily, until they were whittled down by induced population growth. Improvements could be made in specialization and the division of labor, and population growth held in check by such factors as the delay of marriages, but ultimately there was always a limit. This is what Wrigley (1988) called the "advanced organic economy" that can exhibit only "Smithian" growth, as opposed to the "mineral-based energy economy" that can exhibit "Schumpeterian" growth, continuously raising per capita incomes as a result of incessant technical change, accompanied by a demographic revolution that reduces fertility rates to maintain the higher per capita incomes.

If silver was the main commodity in the Atlantic trade of the $17^{\text {th }}$ century there is little doubt that the slave trade and its ramifications dominated that of the $18^{\text {th }}$ century. Africa's participation in the world economy, long confined to the almost-legendary "golden trade of the Moors", grew to major proportions with the expansion of sugar, tobacco and cotton cultivation in the New World on slave plantations. The $18^{\text {th }}$ century accounted for about two-thirds of the total transfer of 9-10 million persons over the entire history of the trade from its inception around 1450 to its abolition in the $19^{\text {th }}$ century. The last two decades of the $18^{\text {th }}$ century in particular saw a surge in slave imports in response to the cotton boom triggered by the onset of the Industrial Revolution in Britain.

This pattern of relationship in the international trade of the Atlantic gave rise to the celebrated thesis of Eric Williams (1944) that the profits of the slave trade spurred the Industrial Revolution. This argument was heavily criticized by several prominent historians but sympathetically treated by William A. Darity, Barbara L. Solow and Findlay (1990), who provides the relevant references as well as a simple general-equilibrium model of the "triangular 
trade" between Europe (largely Britain), Africa and the New World. Patrick K. O'Brien and Stanley L. Engerman (1991) are also somewhat receptive to the William Thesis, after having been among its most prominent critics in earlier work. For a current review and references, see Morgan (2000).

A more general issue is the question of the role of foreign trade as a whole in relation to the origin and sustainability of the Industrial Revolution. The growing importance of international trade for the British economy is indicated by the rise in the share of exports in national income from $8.4 \%$ in 1700 to $14.6 \%$ in 1760 and $15.7 \%$ in 1801 (Crafts 1985, Table 6.6). Even more interesting is the shift in the geographical distribution of British trade reported by Davis (1962). North America, Africa and the West Indies took 12\% of exports and provided $20 \%$ of retained imports in 1700 , with these shares rising to $60 \%$ of exports and $32 \%$ of imports. ${ }^{6}$ Thus the "triangular trade" grew faster than total trade, which in turn grew faster than national income. Findlay (1982) considered a model in which a discrete but substantial technical innovation in the export sector is responsible for the initial spurt, rather than an exogenous shift in foreign demand. The apparent deterioration of Britain's terms of trade in the aftermath of the original spurt is consistent with this "supply-side" explanation; however, it may be that the existence of wide and growing foreign markets made it possible for the impulse from technological change in the export sector not to be choked off by too sharp a decline in relative prices.

The triangular trade model in Findlay (1990) also predicts an expansion of demand for

\footnotetext{
${ }^{6}$ Esteban (1997) presents valuable evidence on the rising share of manufactured exports to industrial output in Britain from 1700 to 1851.
} 
raw cotton imports into Britain and of slaves to the Americas as a consequence of the innovation in Manchester in the $1780 \mathrm{~s}$. There is abundant evidence for both, together with improvements in the terms of trade for the newly independent United States, where cotton was the main export, and also for the slave-exporting kingdoms on the west coast of Africa. One further interesting aspect of the intercontinental complex was the role of Indian cotton textiles. These were a major import of the East India Company, sold to Britain itself and re-exported to Africa in payment for slaves. Ultimately Lancashire, with its raw cotton imports from the slave plantations of the New World, displaced the long-standing Indian cotton textile industry, leading to the sad fate of the handloom weavers of Bengal. "Globalization" was thus fully at work at the turn of the $18^{\text {th }}$ century to the $19^{\text {th }}$ century, with both positive and negative consequences in all four continents.

\section{Section 4. The French and Napoleonic Wars}

The previous sections have documented the growth and maturation of a well-defined global economy encompassing not just Europe and Asia, but Africa and the Americas as well. However, progress towards greater economic integration had been periodically impeded by war, as various European nations struggled for supremacy. This was not a new phenomenon: for example, Russell Menard (1991, pp. 240-243) finds a three-fold increase in freight charges on the English-Continental wine trade during the $14^{\text {th }}$ century, due to the onset of the Hundred Years War. Figure 2 indicates increases in clove and pepper markups during the 1650s and 1660s, coinciding with the first and second Anglo-Dutch Wars (1652-54 and 1665-67); and the spike in the clove mark-up during the 1750s coincides with the outbreak of the Seven Years War (175663). Even more noticeable are the increases in mark-ups during the 1790 s, coinciding with the 
outbreak of what have become known as the French and Napoleonic Wars. On February $1^{\text {st }}, 1793$ the French National Convention declared war on Great Britain. The ensuing period of warfare, which lasted almost uninterrupted until 1815, had profound and long-lasting effects on international trade.

Within a month, the Convention had prohibited the importation of large classes of British goods, and in October it banned all British manufactured goods; meanwhile, the British side adopted a policy of blockading the coast of France. As Eli Heckscher's classic account emphasizes (Heckscher 1922), each side was motivated by a mercantilist desire to prevent the other exporting, and thus acquiring precious metals, rather than by a desire to prevent the other side importing food or other goods which might be useful to the war effort. ${ }^{7}$ In addition, both the French and the British took measures against neutral shipping which transported enemy goods, but trade disruption was to become far more widespread in the aftermath of Napoleon's military victories over Austria in 1805 and Prussia in 1806. In November 1806, his Berlin Decree declared that the British Isles were under blockade (somewhat fancifully, since Britain controlled the seas); he also began applying these restrictions, not just in France, but in vassal states such as Spain, Naples and Holland. The result was that virtually the entire Continent was now in a state of 'self-blockade' against the exports of Britain, the overwhelmingly dominant industrial power of the time. ${ }^{8}$ In November 1807 the British declared that neutral ships could be seized if found to be carrying goods from enemy colonies directly to their mother countries; Napoleon retaliated by

\footnotetext{
${ }^{7}$ The exception being that food exports were occasionally banned when domestic food supplies were scarce.

${ }^{8}$ The only Continental country to hold out was Sweden, which was eventually forced to join the blockade in 1810 .
} 
declaring that any neutral ship putting into a British port was fair prize, and could be seized. Faced with a situation where neutral ships carrying colonial goods to the Continent were now subject to seizure from either one side or the other, the US government closed its ports in December to belligerent shipping and forbade its own ships to leave these ports.

This Embargo Act was repealed in 1809, and replaced with a non-Intercourse Act which only banned trade with Britain and France (and which was clearly difficult to enforce, once ships had been given leave to sail to Europe). Russia broke with France in 1810; by 1813 Napoleon was in retreat and the Continental Blockade was unraveling in several directions; and the Blockade legislation was finally repealed following Napoleon's abdication in 1814. Nonetheless, for over 20 years leading governments had acted so as to severely disrupt international trade, and under the Continental System that disruption had been widespread and rather extreme. Did these measures seriously impede the integration of international commodity markets, or were they so undermined by smuggling, corruption and fiscally-motivated legal exceptions to the general protectionist rule as to have had no significant effect?

The literature on these issues is sparse, and to a large effect relies on qualitative evidence, or quantity data, rather than the price data which we really need. In a classic article, François Crouzet (1964) drew attention to the disruptive effects of the wars on Continental industry. The sea blockade by the British Royal Navy affected Atlantic-oriented export activities severely: ship building, rope-making, sail-making, sugar refining, and the linen industry all suffered. Industrial activity shifted from the Atlantic seaboard to the interior, as import-substituting industries such as cotton textiles flourished behind the protection from British competition afforded by the Continental System. The gains to interior regions such as Alsace were mirrored by the population 
loss in coastal cities such as Amsterdam, Bordeaux and Marseilles. Naturally, Continental industries which had prospered under these wartime circumstances were unlikely to favor peacetime moves towards free trade; the effects of the war-time shock were thus to prove quite persistent, with path-dependence being induced by the political process.

Jeffrey Frankel (1982) has produced more price-based evidence speaking to the issue of how Jefferson's Embargo Act affected trade and welfare in the US and Britain during 1808 and early 1809 . In 1807 , the Liverpool price of cotton was $27.5 \%$ higher than the Charleston price; in the final two months of the embargo, the Liverpool price was $293.3 \%$ higher than the Charleston price (Frankel 1982, pp. 307-8). Using prices for a number of key agricultural and industrial commodities, Frankel found that the British terms of trade deteriorated by between $41.9 \%$ and $49.7 \%$ during the dispute, while the US terms of trade deteriorated by between $31.6 \%$ and $32.7 \%$ (Frankel 1982, p. 304). The smaller impact on the US economy was largely due to its success in developing import-substituting industries in states such as Pennsylvania. As in the French case, these new industries and their home states would form the basis of a powerful protectionist lobby in the years ahead, yet another example of politically-induced hysteresis.

By how much did the wars increase the costs of trade between Britain and the Continent? According to Thomas Tooke, it cost between 30 and 50 shillings per quarter to ship wheat from the Baltic to Britain in 1810, as compared with $4 \mathrm{~s} / 6 \mathrm{~d}$ in $1837 .{ }^{9}$ Glenn Hueckel has estimated that wartime freight, insurance and licence costs accounted for between $25 \%$ and $40 \%$ of British wheat prices in 1812, and that over the period 1790-1815, wartime disruption raised the relative price of agricultural commodities in Britain by $28 \%$ (Hueckel 1973, pp. 369, 389). Not

\footnotetext{
${ }^{9}$ Cited in Hueckel (1973), p. 369.
} 
surprisingly, this raised landowners' incomes significantly (Hueckel 1973, Williamson 1984), and equally unsurprisingly, British landowners tried to hold onto those gains after the war by means of strict protection.

It seems as though the Napoleonic Wars not only managed to disrupt the workings of international commodity markets in the years before 1815; in France and the US the hothouse protection afforded by war created import-substituting industries which would require continuing protection for their survival. The resulting emergence of powerful protectionist constituencies would ensure that the road to free trade in the $19^{\text {th }}$ century would not be as universal or as smooth as is sometimes supposed. North-South conflict over tariff policy would be a feature of American politics for decades to come; Crouzet (1964, p. 588) goes so far as to speculate that the instinctively interventionist French attitude towards protection evident at the time he was writing (the early 1960s) might be traced back to these long run political effects of the Napoleonic Wars.

Moreover, in Britain the Corn Laws survived until 1846. When Europe eventually moved towards freer trade in the late $19^{\text {th }}$ century, this was largely as a result of Britain's example; might Britain have liberalized earlier had the Napoleonic Wars not intervened? Such an argument assumes that industrialization (which would have proceeded more rapidly in the absence of the war ${ }^{10}$ would have led to the emergence of powerful export interests, which would have eventually triumphed as their political power grew. Would the extension of the franchise favoring urban interests have predated the 1832 Reform Act, had war not occurred? Alternatively, might landlords have diversified into non-agricultural interests earlier, and been coopted by the free trade side as eventually happened (Schonhardt-Bailey 1991)? Did the

\footnotetext{
${ }^{10}$ Williamson (1984).
} 
Napoleonic Wars delay the advent of free trade in Britain and Europe, by as much as several decades? We confess that we do not know the answers to these important questions.

\section{Section 5. World trade 1815-1914}

\section{Section 5.1. The world-wide $19^{\text {th }}$ century decline in transport costs ${ }^{11}$}

Although canals also made a significant contribution to commodity market integration (Slaughter 1995), steamships were the most important $19^{\text {th }}$ century innovation in shipping technology. In the first half of the century, steamships were mainly used on rivers, the Great Lakes, and inland seas such as the Baltic and the Mediterranean. A regular trans-Atlantic steam service was inaugurated in 1838, but until 1860 steamers mainly carried high-value goods similar to those carried by airplanes today, like passengers and mail (Cameron 1989, p. 206). As late as 1874, steamships carried 90 percent of the ginger, 90 percent of the poppyseed, 90 percent of the tea and 99 percent of the cowhides from Calcutta to Britain, but only 40 percent of the jute cuttings, and one third of the rice (Fletcher 1958, p. 561).

A series of innovations in subsequent decades helped make steamships more efficient: the screw propeller, the compound engine, steel hulls, bigger size and shorter turn-around time in port. Another important development was the opening of the Suez Canal on November 17, 1869. Far Eastern trade was still dominated by sail: in the absence of sufficient coaling stations around the coast, the trip around Africa by steamer required carrying too much coal. The compound engine reduced fuel requirements, and the Suez Canal made it possible to pick up coal at Gibraltar, Malta and Port Said, in addition to halving the distance from London to Bombay. Not

\footnotetext{
${ }^{11}$ This section draws heavily on O'Rourke and Williamson (1999, Chapter 3).
} 
only did the Suez Canal make it possible for steamships to compete on Asian routes, but it was of no use to sailing ships, who would have to be towed for the roughly one-hundred mile journey. Before 1869, steam tonnage had never exceeded sail tonnage in British shipyards; in 1870, steam tonnage was over twice as great as sail, and sail tonnage only exceeded steam in two years after that date (Fletcher 1958).

The other major $19^{\text {th }}$ century development in transportation was, of course, the railroad. The Liverpool-Manchester line opened in 1830; early Continental emulators included Belgium, France and Germany. The growth in railway mileage during the late $19^{\text {th }}$ century was phenomenal, particularly in the United States, where trains would play a major role in creating a truly national market. Indeed, transport costs between the American Midwest and East Coast fell even more dramatically than trans-Atlantic transport costs during the late $19^{\text {th }}$ century. Drawing on American sources, the British Board of Trade published in 1903 an annual series of transport costs for the wheat trade between Chicago, New York and Liverpool. It cost 6 shillings and 11 pence to ship a quarter of wheat by lake and rail from Chicago to New York in 1868 . The cost using rail alone was $10 \mathrm{~s} / 2 \mathrm{~d}$. The cost of shipping a quarter of wheat from New York to Liverpool by steamer was $4 \mathrm{~s} / 71 / 2 \mathrm{~d} .{ }^{12}$ In 1902 , these costs had fallen to $1 \mathrm{~s} / 11 \mathrm{~d}, 2 \mathrm{~s} / 11 \mathrm{~d}$ and $11 \frac{1}{2} \mathrm{~d}$ respectively. While the percentage decline in trans-Atlantic costs was greater, in absolute terms it was the American railways that did most of the work in reducing price gaps between producer and consumer. ${ }^{13}$ In any case, regional price convergence within the United States was dramatic. The wheat price spread between New York City and Iowa fell from 69 to 19 percent from 1870

\footnotetext{
12 These figures imply that transport costs from Chicago to Liverpool were about 19 percent of the New York wheat price in 1868.

${ }^{13}$ Harley's (1980) data tell a similar story.
} 
to 1910, and from 52 to 10 percent between New York City and Wisconsin (Williamson 1974, p. 259).

The railroad had similar effects elsewhere. Jacob Metzer (1974) provided the evidence for Russia, where railway construction took off after the mid-1860s. He finds a clear decline in St Petersburg-Odessa price gaps for wheat and rye, starting in the 1870s; bilateral grain price differentials declined for a wider sample of nine markets between 1893 and 1913. Corresponding to this price convergence was a growing regional dispersion of wheat and rye production, as regions specialized according to their comparative advantage. John Hurd (1975) has documented the predictable consequences of the railroad for Indian food grain prices, as internal transport costs were reduced by about 80 percent. The coefficient of variation of wheat and rice prices across districts fell from over 40 percent in 1870 to well below 20 percent in the decade before World War I; moreover, the coefficient of variation was consistently higher among India's districts without railways than among districts with railways.

What was the impact of these transport innovations on the cost of moving goods between countries? Knick Harley's (1988) index of British ocean freight rates remains relatively constant between 1740 and 1840, before dropping by about 70\% between 1840 and 1910 . The North (1958) freight rate index among American export routes drops by more than 41 percent in real terms between 1870 and 1910. These two indices imply a decline in Atlantic economy transport costs of about 1.5 percent per annum, or a total of 45 percentage points up to 1913 . The transport revolution was not limited to the Atlantic economy: Harlaftis and Kardasis (2000) have shown that the declines in freight rates between 1870 and 1914 were just as dramatic on routes involving Black Sea and Egyptian ports as on those involving Atlantic ports. Meanwhile, the 
tramp charter rate for shipping rice from Rangoon to Europe, for example, fell from 73.8 to 18.1 percent of the Rangoon price between 1882 and $1914 ;{ }^{14}$ the freight rate on coal (relative to its export price) between Nagasaki and Shanghai fell by 76 percent between 1880 and 1910; and total factor productivity on Japan's tramp freighter routes serving Asia advanced at 2.5 percent per annum in the thirty years between 1879 and 1909 (Yasuba 1978, Tables 1 and 5).

\section{Section 5. $2.19^{\text {th }}$ century trade policy: 2 steps forward, 1 step back ${ }^{15}$}

Paul Bairoch (1989, p. 7) has described European trade policy after Waterloo as 'an ocean of protectionism surrounding a few liberal islands.' Gradually, however, the demand for trade liberalization in Britain grew, partly under the influence of economists like David Ricardo, partly as a result of the growing power of urban interests, symbolized by the Reform Act of 1832 . The pro-globalization movement applied to both commodity and factor markets. Skilled workers were allowed to emigrate in 1825 , an option which had not been available to them since 1719 . A new Corn Law Act in 1828 abandoned import prohibitions for grains, replacing them with a sliding scale tariff which varied inversely with the domestic price of grain. Various tariffs were reduced again in 1833. Robert Peel allowed the export of machinery in 1842 (banned since 1774), abolished the export tax on wool, and reduced protection on grains and other goods still further. Tariffs were again reduced in 1845. Britain finally made the decisive move towards free trade by repealing the Corn Laws in 1846.

The British example was followed by the rest of Europe, but much more slowly:

\footnotetext{
14 The Asian material that follows in this section and later draws on Williamson $(1999,2000)$.

15 This section draws heavily on O'Rourke and Williamson (1999, Chapters 3, 6), who in turn draw heavily on Bairoch (1989), the standard reference on European trade policy in this period.
} 
“...before 1860 only a few small Continental countries, representing only 4\% of Europe's population, had adopted a truly liberal trade policy. These were the Netherlands, Denmark, Portugal and Switzerland, to which we may add Sweden and Belgium (but only from 1856-7 onwards), and even these maintained some degree of protection." (Bairoch 1993, p. 22)

The Cobden Chevalier treaty between France and the United Kingdom was not signed until 23 January 1860, but, though delayed, the signature heralded a decisive shift towards European free trade. The treaty abolished all French import prohibitions, replacing them with ad valorem duties not to exceed 30 percent. Britain reduced wine tariffs by more than 80 percent, admitted many French products duty free, and abolished the export duty on coal. Most importantly, perhaps, the treaty's use of the most-favored-nation (MFN) clause established the principle of non-discrimination as a cornerstone of European commercial practice. The clause stipulated that each country would automatically extend to the other any trade concessions granted to third parties. MFN clauses were inserted into the many bilateral trade treaties that followed in the ensuing years, ensuring that bilateral concessions were generalized to all. France and Belgium signed a treaty in 1861; a Franco-Prussian treaty was signed in 1862; Italy entered the 'network of Cobden-Chevalier treaties' in 1863 (Bairoch 1989, p. 40); Switzerland in 1864; Sweden, Norway, Spain, the Netherlands and the Hanseatic towns in 1865; and Austria in 1866. By 1877 , less than two decades after the Cobden Chevalier treaty and three decades after British Repeal, Germany ‘had virtually become a free trade country’ (Bairoch 1989, p. 41). Average duties on manufactured products had declined to 9-12 percent on the European Continent, a far cry from the 50 percent British tariffs, and 'numerous' prohibitions elsewhere, of the immediate post-Waterloo era (Bairoch 1989, Table 3, p. 6; Table 5, p. 42).

Until the 1870s, therefore, European trade policy trends were reinforcing the impact of 
the transport cost declines outlined earlier. Things would soon change, however. The turning point came in the late 1870 s and 1880 s, when the impact of cheap New World and Russian grain began to make itself felt in European markets: for example, real British land rents fell by over 50 percent between 1870 and 1913. Almost all of this British decline can be attributed to international commodity market integration (O’Rourke and Williamson 1994); more generally, by the late $19^{\text {th }}$ century international trade was having a profound impact on income distribution, lowering the incomes of landowners relative to those of workers throughout Europe (Lindert and Williamson 2001). Wherever landed interests were powerful enough, the legislative reaction was predictable. The German turning point came in 1879, when Bismarck protected both agriculture and industry. While the specific tariffs started low, they were raised in 1885, and again in 1887 , reaching the equivalent of about 33 percent ad valorem on wheat and 47 percent on rye. In France, tariffs were raised in the $1880 \mathrm{~s}$, but the protectionist breakthrough is commonly taken to be 1892 when the Méline tariff was adopted; by 1894, the duty on wheat was equivalent to an $a d$ valorem rate of 32 percent. In Sweden, agricultural protection was reimposed in 1888, and industrial protection was increased in 1892. Italy had been a free trader in the wake of Unification, but shortly thereafter it introduced moderate tariffs in 1878 , followed by rather more severe tariffs in 1887.

There was thus a common pattern across western Europe of liberalization followed by a reversion to protection, prompted by the distributional effects of the grain invasion. There were exceptions: for example, liberalization was both shorter and less dramatic in Iberia. Other small countries were more liberal in the wake of the grain invasion; for example, Denmark adhered to agricultural free trade throughout, switching from being a net grain exporter to a net grain 
importer (feed for its booming animal husbandry). ${ }^{16}$ The Netherlands followed a similar path, maintaining free trade throughout the period. Dutch farmers also adopted improved techniques, and developed a strong export trade in animal products, fruit and vegetables (Tracy 1989, p. 23). Both Belgium and Switzerland maintained free, or nearly free grain imports, although they did impose some duties on animal products, as well as moderate duties on manufactured goods. Most importantly, the United Kingdom also maintained free trade, despite some domestic dissension.

In summary, there was a major retreat from open trade policies in Europe towards the end of the nineteenth century, triggered largely by pressure from landowners. Transport cost declines led to distributional changes, which in turn prompted an attempt by the losers to insulate themselves from the international economy. Moreover, it turns out that countries such as Denmark which retained agricultural free trade were less vulnerable to the agricultural output and land price reductions which globalization implied (O’Rourke 1997). Elsewhere, it seems that globalization undermined itself.

New World landowners benefitted from free trade, of course, but this does not mean that New World trade policy was any more liberal. In the United States, those infant industries mentioned earlier which sprang up during the French Wars had formed the basis for a longstanding Northern pro-tariff lobby: Northern victory in the Civil War had predictable consequences for subsequent tariff policy. Tariffs were raised during the war for revenue purposes, but Republican domination of Congress would ensure that they remained exceptionally high for a very long time thereafter.

\footnotetext{
${ }^{16}$ It did however impose tariffs on various manufactured goods: manufactured textiles faced duties of between 20 and 25 percent (Bairoch 1989, p. 81).
} 
Canada also protected manufacturing, especially after 1878 when the Conservatives were elected on a protectionist platform. In Australia, the Victoria tariff bill of 1865 allowed for maximum ad valorem tariffs of 10 percent, but by 1893, after a succession of tariff increases, the maximum rates stood at 45 percent (Siriwardana 1991, p. 47). The first federal tariff of 1902 represented a compromise between protectionist Victoria and the other more liberal colonies, but protection was greatly strengthened in 1906 and 1908 (Bairoch 1989, pp. 146-7) and it proved to be remarkably enduring.

While the third quarter of the $19^{\text {th }}$ century saw an easing of protection in Latin America, tariffs rose again in the final quarter. Argentina increased tariffs from the 1870s onwards (Bairoch 1989, pp. 150-1). By 1913, average tariffs were almost 35 percent in Uruguay, almost 40 percent in Brazil, and over 45 percent in Venezuela (Bulmer-Thomas 1994, p. 142). It appears that the highest tariff barriers were in the New World, not Europe. The tariffs were directed towards manufactures and they served to favor scarce urban labor and capital while penalizing abundant land.

Late $19^{\text {th }}$ century trade policy thus offset the impact of transport cost declines in both Europe and the New World. The opposite was the case in Asia, where Japan switched from virtual autarky to free trade in 1858 . Other Asian nations - China, Siam, Korea, India and Indonesia - also followed this liberal path, most forced to do so by colonial dominance or gunboat diplomacy. This shift had largely taken place from the $1860 \mathrm{~s}$; from then on, commodity price convergence was driven entirely by sharply declining transport costs in Asia without much change in tariffs one way or the other. 


\section{Section 5.3. $19^{\text {th }}$ century commodity market integration}

What impact did these technological and political developments have on international commodity markets? As we have seen, world trade grew at a little over $1 \%$ per annum between 1500 and 1800 , but it has grown at around $3.5 \%$ per annum since 1820 , with the $19^{\text {th }}$ and $20^{\text {th }}$ century growth rates being roughly equal (Maddison 1995). Indeed, the $19^{\text {th }}$ century growth rate was more impressive than the $20^{\text {th }}$, in the sense that world GDP growth was twice as high since 1913 as it was between 1820 and 1913: the implication is that trade ratios (e.g. the ratio of merchandise exports to GDP) grew more rapidly during the $19^{\text {th }}$ century than they did during the $20^{\text {th }}$. Table 3 documents the eight-fold increase in this ratio worldwide between 1820 and 1913, when merchandise exports accounted for almost $8 \%$ of world GDP, and more than $16 \%$ of western European GDP.

The $19^{\text {th }}$ century marks a dramatic break with the past insofar as intercontinental commodity market integration is concerned, since as we have seen there was little or no intercontinental price convergence prior to 1800 . By contrast, Figure 2 indicated that there was substantial Dutch-Asian price convergence during the $19^{\text {th }}$ century, while late $19^{\text {th }}$ century price convergence more generally has been extensively documented. For example, Liverpool wheat prices exceeded Chicago prices by 57.6 percent in 1870 , by 17.8 percent in 1895 , and by only 15.6 percent in 1913 (O'Rourke and Williamson 1994, based on Harley 1980). LondonCincinnati price differentials for bacon were 92.5 percent in 1870, over 100 in 1880, 92.3 in 1895, and 17.9 in 1913. The Boston-Manchester cotton textile price gap fell from 13.7 percent in 1870 to -3.6 percent in 1913; the Philadelphia-London iron bar price gap fell from 75 to 20.6 percent, while the pig iron price gap fell from 85.2 to 19.3 percent, and the copper price gap fell 
from 32.7 to almost zero; the Boston-London hides price gap fell from 27.7 to 8.7 percent, while the wool price gap fell from 59.1 to 27.9 percent. Commodity price convergence can also be documented for coal, tin and coffee (ibid).

Continental European grain tariffs did succeed in impeding international price convergence (O'Rourke 1997), but O'Rourke and Williamson (1995) document significant price convergence in the British-Swedish case. Meanwhile, in Asia trade policy strengthened the impact of technological developments. ${ }^{17}$ The cotton price spread between Liverpool and Bombay fell from 57 percent in 1873 to 20 percent in 1913, and the jute price spread between London and Calcutta fell from 35 to 4 percent (Collins 1996, Table 4). The same events were taking place even farther east, involving Burma and the rest of Southeast Asia: the rice price spread between London and Rangoon fell from 93 to 26 percent in the four decades prior to 1913 (Collins 1996, Table 4). Finally, the impact of transport revolutions on commodity price convergence involving the eastern Mediterranean was just as powerful. The average percentage by which Liverpool cotton prices exceeded Alexandria price quotes was: 1824-1832 42.1; 1837-1846 63.2; 18631867 40.8; 1882-1889 14.7 and 1890-1899 5.3 (Issawi 1966, pp. 447-8). Commodity market integration in the late $19^{\text {th }}$ century was both impressive in scale, and global in scope: indeed, Third World economies were becoming more rapidly integrated with the rest of the world than their Atlantic economy counterparts during this period (Williamson 2000).

\section{Section 5.4. Trade in the late $19^{\text {th }}$ century: conclusion}

By 1913, international commodity markets were vastly more integrated than they had

\footnotetext{
${ }^{17}$ The remainder of this paragraph draws on O'Rourke and Williamson (2000).
} 
been in 1750, world trade accounted for a far higher share of world output, and a far broader range of goods, including commodities with a high bulk to value ratio, were being transported between continents. These trends, in combination with rapid industrialization in northwest Europe and its overseas offshoots, had a dramatic impact on the worldwide division of labor. By the late $19^{\text {th }}$ century there was a stark distinction between industrial and primary producing economies. According to the available figures (given in Table 4), primary products accounted for between 62 and 64 percent of total world exports in the late $19^{\text {th }}$ century: in 1913, food accounted for 27 percent of world exports, agricultural raw materials for 22.7 percent and minerals for 14 percent. The UK and northwest Europe were net importers of primary products, and net exporters of manufactured goods. North America still exported primary products, but rapid industrialization there was leading to a more balanced trade in manufactures over time. Meanwhile, Oceania, Latin America and Africa exported virtually no manufactured goods, and Asian exports were overwhelmingly composed of primary products; for example, according to Lamartine Yates $(1959$, p. 250$)$ primary products accounted for more than three quarters of India's exports in 1913. By contrast, textiles had still accounted for more than half of the English East India Company's exports to Europe in the late 1750s (Table 1, Panel C). By 1811-12 the share of piecegoods in India's exports had declined to 33\%; the figure was $14.3 \%$ just three years later, and only $3.7 \%$ in 1850-51. By 1910-11 the share of cotton goods in exports had increased to $6 \%$, but this was dwarfed by the share of raw cotton in exports $(17.2 \%)$. ${ }^{18}$ The contrast with the situation 150 years previously was striking; the impact of this changing division of labor on growth in both the core and periphery would become a major subject of economic debate in the

\footnotetext{
${ }^{18}$ Chaudhuri (1983), pp. 842, 844.
} 
$20^{\text {th }}$ century, particularly in the periphery. In turn, this would eventually have significant effects on policy in the developing world.

\section{Section 6. World trade 1914-2000}

\section{Section 6.1. The First World War and its aftermath}

World War I brought the liberal economic order of the late $19^{\text {th }}$ century to an abrupt end: while there were signs of a globalization backlash from the 1870s onwards, 1914 clearly marked a dramatic and discontinuous break with the past. Both sides attempted to disrupt the others' trade, through blockades or U-boat campaigns; even more serious was the centralized control which even traditionally liberal governments, such as the British, imposed on trade and shipping, with scarce cargo space necessitating that government dictate both the composition of imports through a system of quotas, and the allocation of shipping capacity. This was of course part of a more general shift towards massive and unprecedented government intervention in the economy, with military expenditure absorbing $38 \%$ of UK national output during $1916-17$, and $53 \%$ of German national output during 1917 (Feinstein, Temin and Toniolo 1997, p. 189). In Britain, the McKenna tariff of 1915, designed to save on scarce shipping space, was explicitly protectionist. Moreover, this shift was not reversed after the war: the Key Industries Act of 1919 and the Safeguarding of Industries Act of 1921 introduced additional protection (Kindleberger 1989). These acts did not represent widespread and severe protection- at the beginning of the 1930s, only $£ 13 \mathrm{~m}$. worth of imports were subject to these tariffs, compared with the $£ 138 \mathrm{~m}$. subject to traditional revenue duties, and a total import bill of $£ 1030$ m. (Kenwood and Lougheed 1983, p. 216). Nonetheless, they represented a break with Britain's free-trade past. 
Surprisingly, import shares fell only marginally in Britain during the war; it was exports that collapsed (from 20 to $13 \%$ of GDP), as resources were diverted to the war effort and raw materials for export industries were rationed. In France, the import share rose from $20 \%$ before the war to $36.7 \%$ during it; again, exports fell sharply. ${ }^{19}$ Correspondingly, export ratios rose in neutral economies such as Sweden; in Japan; and in North America, where grain production expanded sharply during the war years to meet Allied demand. It was this reorientation of trade, and the consequent supply responses, which led to some of the most destructive long term economic consequences of the war: agricultural over-supply would be a chronic problem contributing to trade tensions after the war. In addition, the absence of European manufactured exports on world markets stimulated the expansion of industrial capacity, above all in the United States and Japan, but also in countries such as India, Australia, and Latin America. Just as excess food supplies would lead to pressures for agricultural protection, so the hothouse stimulation of industrial 'war babies' would lead to post-war demands for industrial protection in India, Australia and Argentina (Kenwood and Lougheed 1983, pp. 185-6; Eichengreen 1994, pp.88-89). Once again, wartime shocks would have a long run impact on trade flows and resource allocation, in part because of their impact on policy. To this by now traditional mechanism was added the impact of the emergence of new nation states in Europe (Feinstein et al. 1997, pp. 2832); while nationalist leaders in today's aspiring nation states, such as Scotland and Quebec, speak of a free-trading future (Alesina and Spolaore 1997), in the early $20^{\text {th }}$ century independence was typically costly from an economic standpoint, involving the adoption of protectionist policies (Johnson 1965).

\footnotetext{
${ }^{19}$ Based on Jones and Obstfeld (1997) and Mitchell (1992).
} 
The end of war did not imply an end to protection. Subsequent British tariff acts have already been mentioned; quantitative restrictions on trade remained prevalent, particularly in Central and South Eastern Europe, due largely to shortages of food, raw materials, and currency problems; meanwhile, anti-dumping legislation was introduced in Japan in 1920, and in Australia, New Zealand, the UK and the US in 1921. In 1922 the United States, whose government was once again in Republican hands, passed the Fordney-McCumber tariff act, which substantially raised tariffs (Kindleberger 1989, pp. 162-3; League of Nations 1942, p. 18; Irwin 1998a, p.328). While quantitative restrictions were eventually abolished, these were replaced with high tariffs; for example, average tariffs on industrial products were $28 \%$ in Yugoslavia, compared with a pre-war figure of 18\%. The corresponding figures for France were $25.8 \%$, as compared with $16.3 \%$; and for Germany they were $19 \%$, as compared with $10 \%$ (Liepmann (1938), cited in Irwin 1993, p. 105).

The international community was active in calling for liberalization, but ultimately ineffectual. Appeals for the resumption of free trade were made by the Supreme Economic Council in 1920, by the Genoa Conference in 1922, and by the World Economic Conference in 1927, among others. In its retrospective on the interwar period, the League of Nations itself (ibid., p. 42) ruefully acknowledged the paradox that "the international conferences unanimously recommended, and the great majority of Governments repeatedly proclaimed their intention to pursue, policies designed to bring about conditions of "freer and more equal trade"; yet never before in history were trade barriers raised so rapidly or discrimination so widely practised" (ibid., p. 101). Few if any commentators have dissented from this negative assessment. The symbol of interwar protection remains the American Smoot-Hawley tariff, whose 
roots lay in the wartime extension of non-European agricultural supplies mentioned earlier. With the resumption of European supplies, overproduction began to be a chronic problem, and agricultural prices fell- wheat prices, for example, fell sharply from 1925. Continental European protection made the situation of New World suppliers worse; while some exporting governments (the Canadians and Americans) attempted to keep domestic prices high, the Soviet Union's aim of earning sufficient revenues to pay for capital equipment imports led it to export more as prices fell, thus exacerbating the problem (Kindleberger 1973, Ch. 4). The fact that Russian peasants' supply curves were upward-sloping, unlike that of their government, inevitably led to conflict, and widespread suffering (Kindleberger 1989, p. 184).

Herbert Hoover thus promised US farmers tariff protection, and called a special session of Congress in early 1929 to deliver on his pledge. The Smoot-Hawley tariff which emerged in mid-1930 protected industry as well as agriculture, and represented a substantial increase in overall protection. ${ }^{20}$ Deflation over the course of the next two years would increase average tariffs by an even greater extent (Crucini 1994; Irwin 1998b). In contrast to the $19^{\text {th }}$ century experience, the United States was now sufficiently important that the tariff triggered a wave of tariff increases in countries such as Canada, France, Italy, Spain and Switzerland (Kindleberger 1989, Jones 1934), although the extent to which the more general rise in tariffs which followed was due to retaliation, as opposed to various domestic causes, remains subject to dispute

\footnotetext{
${ }^{20}$ How substantial depends on how the average tariff is measured: as a share of total imports, tariff revenues in 1931 were around 18\%, which as De Long (1998) points out would have been a low tariff by $19^{\text {th }}$ century standards, and was less than the level attained at the start of the century (De Long 1998, p.358; Eichengreen 1989, p.16). As a share of dutiable imports, however, tariff revenues were higher in 1931 and 1932 than they had been in 1900, and, Irwin claims, the Smoot-Hawley tariffs were "arguably the highest since the Civil War" (Irwin 1998a, p.327).
} 
(Eichengreen 1989, Irwin 1998a). At a minimum, the tariff sent the signal that the United States was not willing to be the unilateral guarantor of open markets that the United Kingdom had been before the war. In any event, the increases were severe: by 1931, average tariffs on foodstuffs had risen to $82.5 \%$ in Germany, $53 \%$ in France, $66 \%$ in Italy, $59.5 \%$ in Austria, and $75 \%$ in Yugoslavia (Liepmann 1938, cited in Irwin 1993, p. 105). Even the traditionally free-trading Netherlands abandoned a three-centuries long tradition of open markets when it intervened to prop up agricultural prices in 1931 (Kindleberger 1989, pp. 178-9).

In 1932 Britain took a decisive move towards protection, establishing $10 \%$ tariffs on a wide variety of imports; for a few months, little Ireland was one of the only free-trade holdouts in Europe, but later that year she succumbed as Éamon de Valera was elected, and embarked on a wholesale trade war with the United Kingdom. In opting for a policy of import substitution, Ireland was typical of primary producers around the periphery, most notably in Latin America, and as in Latin America the policy seemed initially to be successful in insulating the economy from the worst effects of the Great Depression (Diaz Alejandro 1984; O’Rourke 1991).

Certainly, the traditional export-oriented policy seemed no longer to be working: between 1928/9 and $1932 / 3$, the value of exports fell by over $80 \%$ in Chile; by $75-80 \%$ in China; by $70-75 \%$ in Bolivia, Cuba, Malaya, Peru and Salvador; by $65-70 \%$ in a further 13 primary-exporters, and by over 50\% in a further 22 (Kindleberger 1973, p. 191).

The Great Depression was of course a major further reason for the adoption of severe protection, and not just in the periphery. In France, quotas became widespread during the 1930s, while in Germany the Nazi regime instituted 'totalitarian' quantitative controls on foreign trade reminiscent of a war economy. By 1937, 58\% of French imports were covered by some sort of 
quantitative restriction, with the corresponding figures for Switzerland, the Netherlands and Belgium being 52\%, 26\% and 24\% respectively (Haberler 1943, cited in Irwin 1993, p. 108). Irwin (1993) makes the point that there was a trade-off between countries' adherence to monetary orthodoxy and their adherence to free trade orthodoxy: the four countries just mentioned stuck rigidly to the Gold Standard for much of the 1930s, leading to deflation, overvaluation, and balance of payments difficulties. Quantitative restrictions were in large measure a response to these difficulties. In central and Eastern Europe, countries responded to similar problems by following Germany's lead and introducing widespread exchange controls: this "pernicious bilateralism", as Irwin (1993) calls it, combined with the imperial preferences of Britain (established in Ottowa in 1932) and other colonial powers, led to the complete breakdown of the MFN principle of non-discrimination.

Beginning in 1932, there were several signs that at least some countries were trying to moderate, if not reverse, the increases in protectionism of the previous year or two, although the World Economic Conference of 1933 proved a failure. In 1932 what we now know as the three Benelux countries agreed at Ouchy to start cutting tariffs on each others' exports; this agreement came to nothing as it required other countries, with whom the Ouchy group had MFN relations, to waive their MFN rights, which the UK refused to do. The Oslo group, comprising the Ouchy three, plus Denmark, Norway, Sweden and (eventually) Finland, had met in 1930 for discussions on tariff reform, and agreed in the Hague in 1937 to a program of eliminating quotas between member states- on the basis that this would not violate others' MFN rights, which only applied to tariffs. Most importantly, perhaps, the 1932 US Presidential election led to the appointment of the strongly pro-free trade Cordell Hull as Secretary of State. In 1934, the US Reciprocal Trade 
Agreements Act delegated authority to the Executive to conclude trade agreements, which Hull proceeded to do. By 1939, the US had signed 20 treaties with countries accounting for $60 \%$ of its trade, the most important of which was with the UK-although this last treaty only came into effect in 1939, and was soon overtaken by events.

One interesting theme which emerges from the literature on interwar trade policy concerns the role of the MFN principle during the period. As mentioned previously, the common perception is that the MFN clause played a crucial role in the years after 1860 in speeding up Europe's shift to free trade, by generalizing concessions that were being made anyway. By contrast, the literature has not been so kind regarding the impact of the clause during the $1920 \mathrm{~s}$ and 1930s. We have already mentioned the chilling effect which the MFN principle had on the Ouchy group's attempts to promote more rapid regional trade liberalization; more generally, it has long been recognized that once countries are bound together in a web of MFN treaty obligations, and attempt to advance tariff reductions through bilateral deals, a free-rider problem may arise, with all parties waiting to reap the benefits of other parties' agreements. The League of Nations had been a persistent advocate of the principle of non-discrimination, but was forced to admit in 1942, in its review of trade policy in the 1920s, that

"instead of facilitating, the clause tended to obstruct the reduction of tariffs by means of bilateral or multilateral agreements, owing to the reluctance of governments to make concessions which would be generalized by it. This was the result, mainly, of two causes: first, the refusal of the United States to reduce its own very high tariff by negotiation while claiming to benefit from any tariff reduction negotiated between European countries; secondly, the opposition of certain countries-- notably the United Kingdom, the United States and the British Dominions-- to derogations from strict MFN practice permitting the conclusion of regional or similar agreements for tariff reduction, the benefits of which would be limited to the participants" (League of Nations 1942, p. 119). 
How to explain this distinction between the experiences of the 1860 s and 1870 s, and the interwar period? One approach would be to speculate that, in a multi-country situation in which bilateral tariff bargaining might produce multiple equilibria, the introduction of the MFN clause might serve to produce more extreme equilibria, both good and bad. An alternative interpretation of the data is that the 1860 s wave of tariff-cutting succeeded because the bilateral MFN treaties were, initially, discriminatory: once Britain and France had granted each other concessions, the Belgians found themselves at a disadvantage in these markets, and had an incentive to conclude a treaty, and so on. Thus, the MFN treaties of the 1860s in fact constituted an example of what Irwin (1993, p. 112) calls 'progressive' bilateralism, of the sort that Cordell Hull was advocating in the 1930s: in his submission to the 1933 London conference, he proposed that the MFN principle not be invoked to prevent agreements among groups of countries, but suggested that a number of conditions be attached, one of which was that such agreements be "open to the accession of all countries" (Viner 1950, p. 35). ${ }^{21}$

MFN was of course a cornerstone of the post-war GATT, which has seen a dramatic decline in tariff barriers (see below). The initial rounds continued to cut tariffs on the basis of bilateral agreements that were then multilateralized through the MFN principle to all GATT

${ }^{21}$ The latter interpretation would lead to a sanguine view of regional trade agreements; on the other hand, some of the costs of discrimination identified by recent authors have their echoes in the historical record too. For example, the argument that in the absence of the MFN principle, countries may be reluctant to reach bilateral agreements on the grounds that their partners may reach subsequent agreements which "by granting to third countries concessions still greater than those given to themselves, and to which they would have no claim, would render nugatory the concessions which they received" (Viner 1951, p. 107; Bagwell and Staiger 1999), finds support in the failure of the United States (and Sardinia) to negotiate satisfactory trade agreements while pursuing a conditional MFN policy in the $19^{\text {th }}$ century. It was largely as a result of this experience that the US adopted the unconditional form of the MFN in 1923. 
members. (However, initially it was just the richer countries who were involved: less developed countries only joined in from the mid-1960s onwards.) While the initial Geneva round was a success, other rounds, such as Torquay, were less so, and eventually the GATT shifted to multilateral deal-making, which was to prove such a success in the 1960s (Irwin 1995).

\section{Section 6.2. Twentieth century transport costs}

Transport costs continued to fall during the $20^{\text {th }}$ century, but at a slower rate than previously. Isserlis (1938) provides an index of British tramp freight rates from 1869 to 1936. As Figure 4 shows, between 1869/71 and 1911/13 these freight rates (deflated by the Statist wholesale price index) fell by 22 percentage points, a figure which is reduced by the fact that rates increased sharply in 1911 and 1912; fitted values based on a regression of these deflated rates on time and time-squared show a drop of 34 percent. As expected the rates increased sharply during the war, remaining abnormally high until 1920. While they continued to fall until 1925, they never attained their prewar levels, and rose thereafter, with the overall trend between 1921 and 1936 being broadly flat (at a level roughly equal to the 1869 level).

In the most careful study of post-1945 trends to date, David Hummels (1999) concludes that ocean freight rates have actually increased over much of the period. An index of liner shipping prices, calculated by the German Ministry of Transport, rises from 1954 to 1958, is fairly flat until 1970 (despite the introduction of containers in the 1960s), rises through the 1970s, peaks in 1985, and falls sharply thereafter. Deflated by the German GDP deflator, it never

attains its 1960s levels, even as late as 1997; deflated by the US GDP deflator, it only recovers to its 1954 position by 1993. A less representative tramp shipping index, constructed by the 
Norwegian Shipping News, shows that tramp freight rates were constant or increased between 1952 and 1997, when deflated by a commodity price deflator; when deflated by a US GDP deflator they declined over the period as a whole, but were flat or increased over long subperiods. Moreover, the tramp rates, unlike the liner rates, exclude port costs which were sharply rising during the period.

On the other hand, it is important to stress that air freight rates have declined dramatically in the 1950s, 1960s and 1980s, while declining more slowly in the 1990s, and rising in the 1970s. These declines were greatest on North American routes. The result, predictably enough, has been a more than ten-fold increase in the ratio of air to ocean shipments in the years since 1962 (Hummels 1999).

\section{Section 6.3. Late twentieth century trade policies}

If transport cost declines were much less impressive during the late $20^{\text {th }}$ century than they were in the late $19^{\text {th }}$, then it follows that trade liberalization probably played a much greater role in commodity market integration in the later period than it did during the former. Table 5 gives average tariffs on manufactured products in a number of countries for which data are available back to 1913 . It shows clearly the rise in protection during the interwar period, and the decline in tariff barriers since 1950. It also shows that for most of these countries, tariffs are much lower today than in 1913. There are exceptions, of course, notably Britain, as well as certain Asian countries which had a low tariff regime forced upon them by European powers or the United States. Both China and India, for example, have substantially higher tariffs now than in 1913: an extremely important caveat given these countries' populations. As Table 5 suggests, tariffs are 
much higher now in developing countries than in rich countries, while the opposite was more true of the late $19^{\text {th }}$ century. Table 6 gives average tariffs on manufactured goods in Latin America, East Asia and Sub-Saharan Africa during the 1980s and early 1990s: it shows a substantial decline in Latin America, and smaller declines in the other 2 regions. By the early 1990s, these average tariffs stood at $12.5 \%$ in Latin America, 17.1\% in East Asia, and 22.5\% in Sub-Saharan Africa, as compared with figures of 4 or $5 \%$ for the United States, the EU, and Japan.

It is important to remember, of course, that emphasizing industrial tariffs overstates the extent to which industrial countries today have moved towards free trade, since agricultural protection (which triggered the move back towards protection in late $19^{\text {th }}$ century Europe, as well as the protection of the late 1920s) remains extremely high in many wealthy countries, higher certainly than in 1913. Coppel and Durand (1999) report that protection raises the prices received by farmers by about $60 \%$ in Japan, $40 \%$ in the European Union, $15 \%$ in Canada, and $20 \%$ in the United States. Moreover, non-tariff barriers (such as countervailing and anti-dumping duties, quotas, VERs, production subsidies, and technical barriers to trade) are much more important today than they were in 1913. According to Coppel and Durand (1999, Table 2), NTBs became less pervasive in all the major industrial economies between 1988 and 1996, although the use of anti-dumping measures has become more common, and has been on the increase in the EU and outside the OECD. Meanwhile, the average incidence of NTBs on manufactured imports fell in Latin America from $28.4 \%$ in the mid-1980s to $1.8 \%$ in the early 1990 s; it fell from $23.1 \%$ to 5.5\% in East Asia; and it increased from $42.7 \%$ to $45.4 \%$ in Sub-Saharan Africa between 1984-7 and 1988-90 (Rodrik 1999, Table 1.3). For all these reasons one cannot automatically assume 
that average world-wide protection is less severe today than it was in 1913.

Given the increased importance of NTBs, it is difficult to measure long run trends in the overall stance of trade policy, although in principle measures such as the trade restrictiveness index (Anderson and Neary 1994) could do precisely this. Nonetheless, the consensus is that the world is becoming more open; for example, according to Sachs and Warner (1995) all regions have become more open in recent decades. However, Africa still lags well behind the rest of the world: as late as 1992, only 30\% of African countries were judged open by Sachs and Warner, as compared with $86 \%$ of countries in the Latin American and Carribean region, and $67 \%$ of Asian countries (Figure 5).

The reasons for the descent of the interwar economy into protectionism are well understood, and have been touched on above. But what were the fundamentals driving postwar liberalization, and even more importantly, what can explain the different timing of liberalization across regions? The US liberalized almost immediately; as Figure 5, based on Sachs and Warner, suggests, Western Europe waited about 15 years to liberalize, and when it did, it did so in a rush, at the end of the 1950s (although the EPU, ECSC and OEEC had been promoting intra-European trade since the beginning of the decade). By contrast, Latin America became progressively more closed from the 1950s onwards, only opening in the 1980s (along with New Zealand), a quarter century after the Europeans: yet another powerful example of path dependence arising from an exogenous shock (in this case, world depression rather than war), and operating through the political process. The former Communist economies only opened during the 1990s; much of Africa still remains closed.

Were ideas or interests responsible for these differences between regions? On the one 
hand, when countries in Latin America or elsewhere turned to import substitution during the 1930s and 1940s, this created constituencies which now depended on protection, and lobbied for its maintenance; an interest-based explanation would require arguing that for some reason, the protectionist coalitions of capital and labor which characterized Latin America or Australasia were more powerful than similar coalitions which emerged in peripheral European economies, for example. Alternatively, disillusion with the market as a result of the interwar experience led many intellectuals and policy makers to advocate socialism or state-led industrialization which was inimical to open markets. Bodies such as the UN Economic Commission for Latin America were influential in advocating import substitution, and their hostility to free trade was shared by many development economists (Corbo 1992, Krueger 1997). Were these ideas more appealing to developing country elites, and if so why? If ideas explain postwar protection, then disillusion with those ideas must explain eventual liberalization; and indeed, in countries such as Ireland there was deep disillusion with import substitution by the late 1950s. Why did it take longer for the failures of that policy to become apparent elsewhere? And what were the roles of the Cold War in explaining OECD liberalization, or of decolonization in explaining sub-Saharan or Indian protection? Although much work has been done on individual countries and regions, we have not yet seen a comprehensive and comparative account which can explain the diversity of the post1945 experience world-wide.

\section{Section 6.4. Commodity market integration in the $20^{\text {th }}$ century}

What has been the combined impact of the transport cost and trade policy developments documented above? Turning to the volume of trade first, Table 3 shows that merchandise exports 
accounted for a smaller share of world GDP in 1950 than they had done in 1913; and that the 1913 levels of openness (on this measure) had not been recouped as late as 1973 in the UK, Spain, Australia, Latin America, China, India and Thailand. Indeed, consistent with the average tariff data in Table 5, they had not been recouped as late as 1992 in much of the developing world, and in particular in Latin America and India (where they had not even been recouped by 1998).

However, as stressed in the introduction, trade shares may vary because of shifts in export supply or import demand, rather than reflecting changes in international commodity market integration. In addition, the merchandise share of GDP has been shrinking since 1913, which would tend to pull down the share of merchandise exports in GDP, irrespective of globalization trends. As Robert Feenstra (1998), among others, has pointed out, the growth in merchandise trade has been far more impressive relative to merchandise value added than relative to GDP (although even his Table 2, which gives data for advanced countries only, shows Japanese and UK ratios lower in 1990 than in 1913). And other more qualitative criteria, such as the amount of intra-firm trade, associated with outsourcing and what Feenstra calls the 'disintegration of production', also clearly demarcate the present era from the period before World War I.

However, on other criteria the contribution of commodity market integration during the $20^{\text {th }}$ century does not seem so impressive. Baier and Bergstrand (2001) report that income growth explains fully two-thirds of world trade growth between the late 1950s and the late 1980s, leaving only $25 \%$ to tariff reductions, and a mere $8 \%$ to transport costs declines. Strikingly, the share of trade growth due to income growth during the late $20^{\text {th }}$ century is very similar to that during the three centuries following Columbus- a period for which there is little or no evidence 
of commodity market integration (Section 3.4). Whether a much larger share of trade growth in the rapidly globalizing $19^{\text {th }}$ century was due to commodity market integration is not yet known.

Price gaps for identical commodities in different markets remain the best measure of commodity market integration; and yet surprisingly little work has been done collecting such evidence for the $20^{\text {th }}$ century. Presumably the post-1945 trade liberalization documented above has swamped any increases in ocean freight rates, and the result has been price convergence: but this remains purely speculative. ${ }^{22}$ Of course, documenting price convergence requires laborious work in the archives, ensuring that price quotes are for identical goods in various markets; but if the $19^{\text {th }}$ century can yield such evidence for economic historians, then surely the $20^{\text {th }}$ century can do the same?

Finally, what has happened to the composition of trade over the course of the $20^{\text {th }}$ century? Table 7 gives the World Bank's estimates of the shares of primary and manufactured goods in the various regions' exports and imports. Recall that in 1913, primary products had accounted for between 62 and 64 percent of total merchandise exports, with food accounting for $27 \%$, agricultural raw materials for $22.7 \%$ and minerals for $14 \%$. By 1999 , the share of primary products in merchandise exports had declined to $18 \%$, with the shares of food, agricultural raw materials and minerals (including fuel) accounting for a mere $8 \%, 2 \%$ and $8 \%$ respectively of the total. The impact of Third World industrialization comes across clearly from these figures: manufactures now account for more than half of merchandise exports everywhere bar the Middle East and North Africa, and sub-Saharan Africa. Even in the case of Africa, however,

\footnotetext{
${ }^{22}$ Indeed, obvious international sources of price data (e.g. the commodity price data to be found in the World Bank Development Indicators or the IMF's International Financial Statistics) reveal no discernable general trend towards commodity price convergence during the past four decades.
} 
manufactures are now vastly more important than they were on the eve of World War I (compare with Table 4). ${ }^{23}$

\section{Section 7. Conclusions}

There are several themes which have emerged from this survey. The range of goods which have been traded between continents since the Voyages of Discovery has steadily increased over time, and there has been substantial commodity market integration over the period, driven by technology in the $19^{\text {th }}$ century and politics in the late $20^{\text {th }}$ century. However, this trend towards greater market integration was not monotonic; it was periodically interrupted by shocks such as wars and world depressions, or by endogenous political responses to the distributional effects of globalization itself. In some periods politics has reinforced the effects of technology, while in other periods it has offset them. In several cases, severe shocks have had long-run effects on the international integration of commodity markets, as a result of politically induced hysteresis. Finally, we know remarkably little about international commodity market integration during the $20^{\text {th }}$ century.

\footnotetext{
${ }^{23}$ Table 7 also indicates the importance of trade in commercial services, which accounted for $19 \%$ of total exports (i.e. of merchandise exports plus commercial services exports) worldwide in 1999, and for between 10 and $20 \%$ of exports from all regions. In 1913, services had accounted for $22 \%$ of total exports from the UK; commercial service exports accounted for $27 \%$ of UK exports in 1999. For the US, the figures were 8\% in 1913 and 27\% in 1999 (Mitchell 1988; US Department of Commerce 1975; World Bank 2001).
} 


\section{References}

Abu-Lughod, J. [1989], Before European Hegemony: The World System AD 1250-1350 (New York: Oxford University Press).

Alesina, A. and E. Spolaore [1997], "On the Number and Size of Nations," Quarterly Journal of Economics 112: 1027-56.

Anderson, J. E. and J. P. Neary [1994], "Measuring the Restrictiveness of Trade Policy," The World Bank Economic Review 8: 151-69.

Bagwell, K. and R.W. Staiger [1999], "Multilateral Trade Negotiations, Bilateral Opportunism and the Rules of GATT," NBER Working Paper 7071, National Bureau of Economic Research, Cambridge, Mass. (April).

Baier, S.L. and J.H. Bergstrand [2001], "The Growth of World Trade: Tariffs, Transport Costs, and Income Similarity," Journal of International Economics 53: 1-27.

Bairoch, P. [1989], "European Trade Policy, 1815-1914," in P. Mathias and S. Pollard (eds.), The Cambridge Economic History of Europe, vol. III (Cambridge: Cambridge University Press).

Bairoch, P. [1993], Economics and World History: Myths and Paradoxes (Chicago: University of Chicago Press).

Baldwin, R.E. and P. Martin [1999], "Two Waves of Globalization: Superficial Similarities, Fundamental Differences," NBER Working Paper 6904, National Bureau of Economic Research, Cambridge, Mass. (January).

Barrett, W. [1990], "World Bullion Flows, 1450-1800" in J. Tracy (ed.), The Rise of Merchant Empires: Long-Distance Trade in the Early Modern World 1350-1750 (Cambridge : Cambridge University Press).

Bulbeck, D., A. Reid, L. C. Tan and Y. Wu [1998], Southeast Asian Exports since the $14^{\text {th }}$ Century: Cloves, Pepper, Coffee and Sugar (Leiden, KITLV Press).

Bulmer-Thomas, V. [1994], The Economic History of Latin America Since Independence (Cambridge: Cambridge University Press).

Cameron, R. [1989], A Concise Economic History of the World from Paleolithic Times to the Present (New York: Oxford University Press).

Chaudhuri, K.N. [1978], The Trading World of Asia and the English East India Company 1660-1760 (Cambridge: Cambridge University Press).

Chaudhuri, K.N. [1983], "Foreign Trade and the Balance of Payments (1757-1947)," in D. Kumar (ed.), The Cambridge Economic History of India Vol. 2: c. 1757-c. 1970 (Cambridge: Cambridge University Press).

Collins, W. J. [1996], "Regional Labor Markets in British India," mimeo., Department of Economics, Harvard University (November).

Coppel, J. and M. Durand [1999], "Trends in Market Openness," OECD Economics Department Working Papers No. 221 (Paris).

Corbo, V. [1992], Development Strategies and Policies in Latin America: A Historical Perspective (San Francisco: International Center for Economic Growth/ICS Press).

Crafts, N. F. R. [1985], British Economic Growth During the Industrial Revolution (Oxford: Clarendon Press).

Crouzet, F. [1964], "Wars, Blockade, and Economic Change in Europe, 1792-1815," Journal of Economic History 24: 567-588.

Crucini, M.J. [1994], "Sources of Variation in Real Tariff Rates: The United States, 1900-1940," American Economic Review 84: 732-43.

Day, J. [1978], "The Great Bullion Famine of the Fifteenth Century," Past and Present 79: 3-54. 
Davis, R. [1962], "English Foreign Trade, 1700-1774,” Economic History Review 15: 285-303.

Davis, R. [1966], “The Rise of Protection in England, 1689-1786," Economic History Review, $2^{\text {nd }}$ Ser. 19: 306-317.

De Long, J.B. [1998], “Trade Policy and America's Standard of Living: A Historical Perspective," in S.M. Collins (ed.), Imports, Exports, and the American Worker (Washington D.C.: Brookings Institution).

Diaz Alejandro, C. [1984], "Latin America in the 1930s," in Thorp, R. (ed.), Latin America in the 1930s: The Role of the Periphery in World Crisis (Macmillan).

Eichengreen, B. [1989], "The Political Economy of the Smoot-Hawley Tariff," Research in Economic History 12: 1-43.

Eichengreen, B. [1994], Golden Fetters: The Gold Standard and the great Depression 1919-1939 (Oxford: Oxford University Press).

Esteban, J. C. [1997], "The Rising Share of British Industrial Exports in Industrial Output, 1700-1851," Journal of Economic History 57: 879-906.

Feenstra, R. [1998], "Integration of Trade and Disintegration of Production in the Global Economy," Journal of Economic Perspectives 12: 31-50.

Feinstein, C.H., P. Temin and G. Toniolo [1997], The European Economy Between the Wars (Oxford: Oxford University Press).

Feuerwerker, A. [1990], "Chinese Economic History in Comparative Perspective," in P. S. Ropp (ed.), Heritage of China (Berkeley and Los Angeles: University of California Press).

Findlay, R. [1982], "Trade and Growth in the Industrial Revolution," in C. P. Kindleberger and G. Di Tella eds.), The Long View in Economics: Essays in Honor of W. W. Rostow , vol. 1 (London: Macmillan).

Findlay, R. [1990], "The Triangular Trade and the Atlantic Economy of the Eighteenth Century: A Simple General-Equilibrium Model," [Frank D. Graham Lecture], Essays in International Finance 177 (Princeton: Princeton University Press).

Findlay, R. [1996], "The Emergence of the World Economy: Towards a Historical Perspective 10001750," Columbia University Economics Discussion Paper No. 9596-08 [April].

Findlay, R. and M. Lundahl [2000], "Towards a Factor Proportions Approach to Economic History: Population, Precious Metals and Prices from the Black Death to The Price Revolution", manuscript.

Flynn, D. O. and A. Giraldez [1995], "Born with a "Silver Spoon": The Origin of World Trade in 1571," Journal of World History 6: 201-221.

Fletcher, M. E. [1958], “The Suez Canal and World Shipping, 1869-1914,” Journal of Economic History 18: 556-73.

Frankel, J.A. [1982], “The 1808-1809 Embargo against Great Britain,” Journal of Economic History 42: 291-307.

von Glahn, R. [1996], "Myth and Reality of China’s Seventeenth- Century Monetary Crisis," Journal of Economic History 56: 429-454.

Haberler, G. [1943], Quantitative Trade Controls: Their Causes and Nature (Geneva: League of Nations).

Hardach, G. [1977], The First World War 1914-1918 (London: Allen Lane).

Harlaftis, G. and Kardasis, V. [2000], "International Shipping in the Eastern Mediterranean and the Black Sea: Istanbul as a Maritime Centre, 1870-1910," in Ş. Pamuk and J.G. Williamson (eds.), The Mediterranean Response to Globalization before 1950 (London: Routledge).

Harley, C. K. [1980], "Transportation, the World Wheat Trade, and the Kuznets Cycle, 1850-1913," Explorations in Economic History 17: 218-50. 
Harley, C. K. [1988], “Ocean Freight Rates and Productivity, 1740-1913: The Primacy of Mechanical Invention Reaffirmed," Journal of Economic History 48: 851-76.

Hamilton, E.J. [1934], American Treasure and the Price Revolution in Spain, 1501-1650 (Cambridge, Mass.: Harvard University Press).

Heckscher, E.F. [1922], The Continental System: An Economic Interpretation (Oxford: Clarendon Press).

Herlihy, D. [1997], The Black Death and the Transformation of the West (Cambridge, Massachusetts: Harvard University Press).

Ho, P. T. [1959], Studies on the Population of China, 1368-1953 (Cambridge, Massachusetts: Harvard University Press).

Hobsbawm, E.J. [1954] "The General Crisis of the European Economy in the $17^{\text {th }}$ Century," Past and Present, 5: 33-53 and 6: 44-65.

Hueckel, G. [1973], "War and the British Economy, 1793-1815: A General Equilibrium Analysis," Explorations in Economic History 10: 365-396.

Hummels, D. [1999], "Have International Transportation Costs Declined?" mimeo, University of Chicago (September).

Hurd, J. [1975], "Railways and the Expansion of Markets in India, 1861-1921," Explorations in Economic History 12: 263-88.

Irwin, D.A. [1991], "Mercantilism as Strategic Trade Policy: the Anglo-Dutch Rivalry For the East India Trade," Journal of Political Economy 99: 1296-1314.

Irwin, D.A. [1993], "Multilateral and Bilateral Trade Policies in the World Trading System: An Historical Perspective," in J. de Melo and A. Panagariya (eds.), New Dimensions in Regional Integration (Cambridge: Cambridge University Press).

Irwin, D.A. [1995], “The GATT's Contribution to Economic Recovery in Post-war Western Europe," in B. Eichengreen (ed.), Europe's Post-war Recovery (Cambridge: Cambridge University Press).

Irwin, D.A. [1998a], "From Smoot-Hawley to Reciprocal Trade Agreements: Changing the Course of U.S. Trade Policy in the 1930s," in M. Bordo, C. Goldin and E. White (eds.), The Defining Moment: The Great Depression and the American Economy in the Twentieth Century (Chicago: University of Chicago Press).

Irwin, D.A. [1998b], "Changes in U.S. Tariffs: The Role of Import Prices and Commercial Policies," American Economic Review 88: 1015-26.

Irwin, D.A. [1998c], "The Smoot-Hawley Tariff: A Quantitative Assessment," Review of Economics and Statistics 80: 326-334.

Israel, J.I. [1989], Dutch Primacy in World Trade 1585-1740 (Oxford: Clarendon Press).

Issawi, C. [1966], The Economy of the Middle East 1800-1914 (Chicago: University of Chicago Press).

Isserlis, L. [1938], “Tramp Shipping Cargoes and Freights,” Journal of the Royal Statistical Society 101, Pt. 1: 304-417.

Iwao, S. [1976], "Japanese Foreign Trade in the $16^{\text {th }}$ and $17^{\text {th }}$ Centuries," Acta Asiatica 30: 1-18.

Johnson, H.G. [1965], "A Theoretical Model of Economic Nationalism in New and Developing States," Political Science Quarterly 80: 169-85.

Jones, J.M. [1934], Tariff Retaliation: Repercussions of the Hawley-Smoot Bill (Philadelphia: University of Pennsylvania Press).

Jones, M.T. and M. Obstfeld [1997], "Saving, Investment, and Gold: A Reassessment of Historical Current Account Data”, NBER Working Paper No. 6103 (Cambridge, Massachusetts: July).

Kenwood, A.G. and A.L. Lougheed [1983], The Growth of the International Economy 1820-1980: An Introductory Text $2^{\text {nd }}$. ed. (London: Unwin Hyman).

Kindleberger, C. P. [1973], The World in Depression (Boston: Little, Brown). 
Kindleberger, C.P. [1989], "Commercial Policy Between the Wars," in P. Mathias and S. Pollard (eds.), The Cambridge Economic History of Europe, vol. III (Cambridge: Cambridge University Press).

Kindleberger, C.P. [1996], World Economic Primacy 1500-1990 (Oxford: Oxford University Press). Krueger, A.O. [1997], “Trade Policy and Economic Development: How We Learn,” American

Economic Review 87: 1-22.

Lamartine Yates, P. [1959], Forty Years of Foreign Trade (New York: Macmillan).

League of Nations [1942], Commercial Policy in the Interwar Period: International Proposals and National Policies (Geneva).

Liepmann, H. [1938], Tariff Levels and the Economic Unity of Europe (London: Allen and Unwin).

Lindert, P.H. and J.G. Williamson (2001), "Does Globalization Make the World More Unequal?" NBER Working Paper 8228, National Bureau of Economic Research, Cambridge, Mass. (April) (forthcoming in this volume).

Livi-Bacci, M. [1997], A Concise History of World Population, Second Edition (Oxford: Blackwell). Maddison, A. [1991] Dynamic Forces in Capital Development, (Oxford: Oxford University Press). Maddison, A. [1995], Monitoring the World Economy 1820-1992 (Paris: OECD).

Maddison, A. [2001], World Development Indicators 2001 (Washington D.C.: World Bank).

Mauro, F. [1961], "Towards an "Intercontinental Model": European Overseas Expansion Between 1500 and 1800," Economic History Review 14: 1-17.

Menard, R. [1991], "Transport Costs and Long-Range Trade, 1300-1800: Was There a European 'Transport Revolution' in the Early Modern Era?” in J. D. Tracy (ed.), Political Economy of Merchant Empires (Cambridge: Cambridge University Press).

Metzer, J. [1974], "Railroad Development and Market Integration: The Case of Tsarist Russia," Journal of Economic History 34: 529-50.

Mitchell, B.R. [1988], British Historical Statistics (Cambridge: Cambridge University Press).

Mitchell, B.R. [1992], International Historical Statistics: Europe 1750-1988 $3^{\text {rd }}$ ed. (New York: Stockton Press).

Morgan, K. [2000], Slavery, Atlantic Trade and the British Economy 1660-1800, (Cambridge: Cambridge University Press).

Neal, L. [1991], “A Tale of Two Revolutions: International Capital Flows 1789-1819,” Bulletin of Economic Research 43: 57-92.

Needham, J. [1954], Science and Civilization in China, vol. 1 (Cambridge: Cambridge University Press).

North, D. C. [1958], “Ocean Freight Rates and Economic Development 1750-1913,” Journal of Economic History 18: 538-55.

O'Brien, P. K. and S. L. Engerman [1991], "Exports and the Growth of the British Economy from the Glorious Revolution to the Peace of Amiens," in B. L. Solow (ed.), Slavery and the Rise of the Atlantic System (Cambridge: Cambridge University Press).

O'Rourke, K.H. [1991], "Burn Everything British but their Coal: The Anglo-Irish Economic War of the 1930's," Journal of Economic History 51: 357-366.

O'Rourke, K.H. [1997], “The European Grain Invasion, 1870-1913,” Journal of Economic History 57: 775-801.

O'Rourke, K. H. and J. G. Williamson [1994], "Late 19th Century Anglo-American Factor Price Convergence: Were Heckscher and Ohlin Right?" Journal of Economic History 54: 892-916.

O'Rourke, K. H. and J. G. Williamson [1995], "Open Economy Forces and Late 19th Century Swedish Catch-Up: A Quantitative Accounting," Scandinavian Economic History Review 43: 171-203. 
O'Rourke, K.H. and J.G. Williamson [1999], Globalization and History: The Evolution of a Nineteenth Century Atlantic Economy (Cambridge, MA: MIT Press).

O'Rourke, K.H. and J.G. Williamson [2000], "When Did Globalization Begin?" NBER Working Paper 7632, National Bureau of Economic Research, Cambridge, Mass. (April) (forthcoming, European Review of Economic History).

O'Rourke, K.H. and J.G. Williamson [2001], "After Columbus: explaining the global trade boom 15001800," NBER Working Paper 8186, Cambridge, MA (March).

Panikkar, K.M. [1953], Asia and Western Dominance (London: George Allen and China).

Parker, G. and L. Smith [1978] (eds.), The General Crisis of the Seventeenth Century (London: Routledge and Kegan Paul).

Prakesh, O. [1998], European Commercial Enterprise in Pre-Colonial India (The New Cambridge Economic History of India II.5; Cambridge: Cambridge University Press).

Rapp, R. T. [1975], “The Unmaking of the Mediterranean Trade Hegemony,” Journal of Economic History 35: 499-525.

Rodrik, D. [1999], The New Global Economy and Developing Countries: Making Openness Work (Washington DC: ODC).

Rossabi, M. [1990], “The 'Decline' of the Central Asian Caravan Trade,” in J.D. Tracy (ed.), The Rise of the Merchant Empires: Long-Distance Trade in the Early Modern World 1350-1750 (Cambridge: Cambridge University Press).

Sachs, J. D. and A. Warner [1995], "Economic Reform and the Process of Global Integration,"

Brookings Papers on Economic Activity, I (Washington, D.C.: Brookings Institution).

Schonhardt-Bailey, C. [1991], "Specific Factors, Capital Markets, Portfolio Diversification, and Free Trade: Domestic Determinants of the Repeal of the Corn Laws," World Politics 43: 545-69.

Siriwardana, A.M. [1991], "The Impact of Tariff Protection in the Colony of Victoria in the Late Nineteenth Century: A General Equilibrium Analysis," Australian Economic History Review 31: 45-65.

Slaughter, M. J. [1995], "The Antebellum Transportation Revolution and Factor-Price Convergence,” NBER Working Paper 5303, National Bureau of Economic Research, Cambridge, Mass. (October).

Steensgaard, N. [1982], "The Dutch East India Company as an Institutional Innovation," in M. Aymard (ed.), Dutch Capitalism and World Capitalism (Cambridge: Cambridge University Press).

Steensgaard, N. [1995], "Commodities, Bullion and Services in Intercontinental Transactions Before 1750," in H. Pohl (ed.), The European Discovery of The World and its Economic Effects on Pre-Industrial Society (Stuttgart: Franz Steiner Verlag).

Tracy, M. [1989], Government and Agriculture in Western Europe 1880-1988, ${ }^{\text {rd }}$ ed. (New York: Harvester Wheatsheaf).

U. S. Department of Commerce [1975], Historical Statistics of the United States: Colonial Times to 1970, Part 2 (Washington, D.C.: USGPO).

Viner, J. [1948], "Power Versus Plenty as Objectives of Foreign Policy in the Seventeenth and Eighteenth Centuries," World Politics 1: 1-29.

Viner, J. [1950], The Customs Union Issue (New York: Carnegie Endowment for International Peace). Viner, J. [1951], International Economics (Glencoe, IL: Free Press).

de Vries, J. and A. van der Woude [1997], The First Modern Economy: Success, Failure and

Perseverance of the Dutch Economy, 1500-1815 (Cambridge: Cambridge University Press).

Wake, C. H. H. [1979], "The Changing Pattern of Europe's Pepper and Spice Imports, 1400-1700,"

Journal of European Economic History 8: 361-403.

Wallerstein, I. [1980], The Modern World System, vol. II (New York: Wiley). 
Williams, E. [1944], Capitalism and Slavery (Chapel Hill: University of North Carolina Press).

Williamson, J. G. [1974], Late Nineteenth Century American Development: A General Equilibrium History (Cambridge: Cambridge University Press).

Williamson, J.G. [1984], "Why was British Growth so Slow During the Industrial Revolution?," Journal of Economic History 44: 687-712.

Williamson, J.G. [1999], "Globalization, Factor Prices and Living Standards in Asia Before 1940," in A. J. Latham (ed.), Asia Pacific Dynamism 1500-2000, (London: Routledge, forthcoming).

Williamson, J.G. [2000], "Land, Labor and Globalization in the Pre-Industrial Third World," NBER Working Paper 7784, National Bureau of Economic Research, Cambridge, Mass. (July) (forthcoming, Journal of Economic History 2002).

Williamson, J. G. and P. H. Lindert [1980], American Inequality: A Macroeconomic History (New York: Academic Press).

Wilson, C.H. [1949], "Treasure and Trade Balances: The Mercantilist Problem,” Economic History Review, 2nd ser. 2: 152-161.

World Bank [2001], World Development Indicators 2001 (Washington D.C.: World Bank).

Wrigley, E.A. [1988], Continuity, Chance and Change: the Character of the Industrial Revolution in England (Cambridge: Cambridge University Press).

Yasuba, Y. [1978], "Freight Rates and Productivity in Ocean Transportation for Japan, 1875-1943," Explorations in Economic History 15: 11-39. 
Table 1. Composition of European overseas imports, 1513-1780

\begin{tabular}{|c|c|c|c|c|c|c|}
\hline \multicolumn{7}{|c|}{ Panel A. Imports from Asia to Lisbon, 1513-1610 (\% by weight) } \\
\hline & 1513-19 & 1523-31 & $1547-8$ & 1587-8 & $1600-3$ & $1608-10$ \\
\hline Pepper & 80.0 & 84.0 & 89.0 & 68.0 & 65 & 69.0 \\
\hline Other spices & 18.4 & 15.6 & 9.6 & 11.6 & 16.2 & 10.9 \\
\hline Indigo & 0.0 & 0.0 & 0.0 & 8.4 & 4.4 & 7.7 \\
\hline Textiles & 0.2 & 0.0 & 0.0 & 10.5 & 12.2 & 7.8 \\
\hline Misc. & 1.4 & 0.4 & 1.4 & 1.5 & 2.2 & 4.6 \\
\hline Total & 100.0 & 100.0 & 100.0 & 100.0 & 100.0 & 100 \\
\hline \multicolumn{7}{|c|}{ Panel B. Imports of VOC into Europe, $1619-1780$ (\% by invoice value) } \\
\hline & 1619-21 & $1648-50$ & $1668-70$ & 1698-1700 & 1738-40 & 1778-80 \\
\hline Pepper & 56.5 & 50.4 & 30.5 & 11.2 & 8.1 & 9 \\
\hline Other spices & 17.6 & 17.9 & 12.1 & 11.7 & 6.1 & 3.1 \\
\hline Textiles & 16.1 & 14.2 & 36.5 & 54.7 & 41.1 & 49.5 \\
\hline Tea and coffee & & & & 4.2 & 32.2 & 27.2 \\
\hline Drugs, perfumes and dye-stuffs & 9.8 & 8.5 & 5.8 & 8.3 & 2.8 & 1.8 \\
\hline Sugar & & 6.4 & 4.2 & 0.2 & 3.7 & 0.6 \\
\hline Saltpetre & & 2.1 & 5.1 & 3.9 & 2.6 & 4.4 \\
\hline Metals & 0.1 & 0.5 & 5.7 & 5.3 & 1.1 & 2.7 \\
\hline Misc. & & 0.2 & 0.1 & 0.4 & 2.3 & 1.7 \\
\hline Total & 100.0 & 100.0 & 100.0 & 100.0 & 100.0 & 100 \\
\hline \multicolumn{7}{|c|}{ Panel C. Imports of English East India Company into Europe, 1668-1760 (\% of invoice value) } \\
\hline & $1668-70$ & 1698-1700 & 1738-40 & 1758-60 & & \\
\hline Pepper & 25.25 & 7.02 & 3.37 & 4.37 & & \\
\hline Textiles & 56.61 & 73.98 & 69.58 & 53.51 & & \\
\hline Raw silk & 0.6 & 7.09 & 10.89 & 12.27 & & \\
\hline Tea & 0.03 & 1.13 & 10.22 & 25.23 & & \\
\hline Coffee & 0.44 & 1.93 & 2.65 & & & \\
\hline Indigo & 4.25 & 2.82 & & & & \\
\hline Saltpetre & 7.67 & 1.51 & 1.85 & 2.97 & & \\
\hline Misc. & 5.15 & 4.52 & 1.44 & 1.65 & & \\
\hline Total & 100 & 100 & 100 & 100 & & \\
\hline \multicolumn{7}{|c|}{ Panel D. Estimated annual sales of colonial imports, England and Netherlands, 1751-4 } \\
\hline & \multirow{2}{*}{\multicolumn{2}{|c|}{ Total sales (1000 pesos) }} & \multicolumn{4}{|c|}{ Percentage of sales } \\
\hline & & & \multicolumn{2}{|c|}{ From Asia } & \multicolumn{2}{|c|}{ Of total } \\
\hline Textiles & \multicolumn{2}{|c|}{6750} & \multicolumn{2}{|c|}{41.7} & \multicolumn{2}{|c|}{21.1} \\
\hline Pepper & \multicolumn{2}{|c|}{1100} & \multicolumn{2}{|c|}{6.8} & \multicolumn{2}{|c|}{3.4} \\
\hline Tea & \multicolumn{2}{|c|}{2800} & \multicolumn{2}{|c|}{17.3} & \multicolumn{2}{|c|}{8.7} \\
\hline Coffee & \multicolumn{2}{|c|}{1000} & \multicolumn{2}{|c|}{6.2} & \multicolumn{2}{|c|}{3.1} \\
\hline Spices & \multicolumn{2}{|c|}{1850} & \multicolumn{2}{|c|}{11.4} & & \\
\hline Misc. & & & & & & \\
\hline Total from Asia & & & & & & \\
\hline & & & From & merica & & otal \\
\hline Sugar & & & & & & \\
\hline Tobacco & & & & & & \\
\hline Misc. & & & & & & \\
\hline Total from America & & & & & & \\
\hline Total overseas imports & & & & & & \\
\hline
\end{tabular}

Sources: Prakesh (1998), pp. 36, 115, 120; Steensgaard (1995), p.12. 
Table 2. Inter-continental silver flows, 1501-1800 (average annual)

\begin{tabular}{|c|c|c|c|c|c|c|c|}
\hline \multirow[t]{2}{*}{ Years } & \multirow{2}{*}{$\begin{array}{c}\begin{array}{c}\text { American } \\
\text { production }\end{array} \\
\text { (Tonnes) }\end{array}$} & \multicolumn{2}{|r|}{$\begin{array}{c}\text { European } \\
\text { imports }\end{array}$} & \multicolumn{2}{|r|}{$\begin{array}{c}\text { European } \\
\text { exports }\end{array}$} & \multicolumn{2}{|r|}{$\begin{array}{c}\text { Asian } \\
\text { imports }\end{array}$} \\
\hline & & (Tonne & $\begin{array}{l}\text { s) (\% of Americar } \\
\text { production) }\end{array}$ & & $\begin{array}{r}\text { s) (\% of Europ } \\
\text { imports })\end{array}$ & (Tonnes) & $\begin{array}{c}\text { (\% of American } \\
\text { production) }\end{array}$ \\
\hline $1501-1525$ & 45 & 40 & 88.9 & & & & \\
\hline $1526-1550$ & 125 & 105 & 84.0 & & & & \\
\hline $1551-1575$ & 240 & 205 & 85.4 & & & & \\
\hline $1575-1600$ & 290 & 205 & 70.7 & & & 2.4 & 0.8 \\
\hline $1601-1625$ & 340 & 245 & 72.1 & 100 & 40.8 & 17 & 5.0 \\
\hline $1626-1650$ & 395 & 290 & 73.4 & 125 & 43.1 & 16 & 4.1 \\
\hline $1651-1675$ & 445 & 330 & 74.2 & 130 & 39.4 & 6 & 1.3 \\
\hline $1676-1700$ & 500 & 370 & 74.0 & 155 & 41.9 & 15 & 3 \\
\hline $1701-1725$ & 550 & 415 & 75.5 & 190 & 45.8 & 15 & 2.7 \\
\hline $1726-1750$ & 650 & 500 & 76.9 & 210 & 42 & 15 & 2.3 \\
\hline $1751-1775$ & 820 & 590 & 72 & 215 & 36.4 & 15 & 1.8 \\
\hline $1776-1800$ & 940 & 600 & 63.8 & 195 & 32.5 & 20 & 2.1 \\
\hline
\end{tabular}

Source: Barrett (1990), Tables 7.3, 7.6. 
Table 3. Merchandise exports as a share of GDP (percent)

\begin{tabular}{lcccccccc}
\hline Country & 1820 & 1870 & 1913 & 1929 & 1950 & 1973 & 1992 & 1998 \\
\hline France & 1.3 & 4.9 & 7.8 & 8.6 & 7.6 & 15.2 & 22.9 & 28.7 \\
Germany & na & 9.5 & 16.1 & 12.8 & 6.2 & 23.8 & 32.6 & 38.9 \\
Netherlands & na & 17.4 & 17.3 & 17.2 & 12.2 & 40.7 & 55.3 & 61.2 \\
UK & 3.1 & 12.2 & 17.5 & 13.3 & 11.3 & 14.0 & 21.4 & 25.0 \\
Total Western Europe & na & 10.0 & 16.3 & 13.3 & 9.4 & 20.9 & 29.7 & na \\
Spain & 1.1 & 3.8 & 8.1 & 5.0 & 3.0 & 5.0 & 13.4 & 23.5 \\
USSR/Russia & na & na & 2.9 & 1.6 & 1.3 & 3.8 & 5.1 & 10.6 \\
Australia & na & 7.1 & 12.3 & 11.2 & 8.8 & 11.0 & 16.9 & 18.1 \\
Canada & na & 12.0 & 12.2 & 15.8 & 13.0 & 19.9 & 27.2 & na \\
USA & 2.0 & 2.5 & 3.7 & 3.6 & 3.0 & 4.9 & 8.2 & 10.1 \\
Argentina & na & 9.4 & 6.8 & 6.1 & 2.4 & 2.1 & 4.3 & 7.0 \\
Brazil & na & 12.2 & 9.8 & 6.9 & 3.9 & 2.5 & 4.7 & 5.4 \\
Mexico & na & 3.9 & 9.1 & 12.5 & 3.0 & 1.9 & 6.4 & 10.7 \\
Total Latin America & na & 9.0 & 9.5 & 9.7 & 6.2 & 4.6 & 6.2 & na \\
China & na & 0.7 & 1.7 & 1.8 & 2.6 & 1.5 & 2.3 & 4.9 \\
India & na & 2.6 & 4.6 & 3.7 & 2.9 & 2.0 & 1.7 & 2.4 \\
Indonesia & na & 0.9 & 2.2 & 3.6 & 3.4 & 5.1 & 7.4 & 9.0 \\
Japan & na & 0.2 & 2.4 & 3.5 & 2.2 & 7.7 & 12.4 & 13.4 \\
Korea & 0.0 & 0.0 & 1.2 & 4.5 & 0.7 & 8.2 & 17.8 & 36.3 \\
Taiwan & -- & -- & 2.5 & 5.2 & 2.5 & 10.2 & 34.4 & na \\
Thailand & na & 2.2 & 6.8 & 6.6 & 7.0 & 4.1 & 11.4 & 13.1 \\
Total Asia & na & 1.3 & 2.6 & 2.8 & 2.3 & 4.4 & 7.2 & na \\
World & 1.0 & 4.6 & 7.9 & 9.0 & 5.5 & 10.5 & 13.5 & 17.2 \\
\hline & & & & & & & &
\end{tabular}

Source: Maddison (1995, p. 38). These have been updated for some countries using Maddison (2001, p.363); and for other countries using the raw export and GDP data given in Maddison (2001), where these produced results consistent with the earlier data series. na = not available. 
Table 4. World trade, $1876-80$ and 1913

\begin{tabular}{|c|c|c|c|c|c|c|}
\hline & \multicolumn{6}{|c|}{ Primary products } \\
\hline & \multicolumn{3}{|c|}{ 1876-80 } & \multicolumn{3}{|c|}{1913} \\
\hline Region & Exports & Imports & Balance & Exports & Imports & Balance \\
\hline USA and Canada & 600 & 330 & 270 & 2101 & 1542 & 559 \\
\hline UK & 117 & 1362 & -1245 & 760 & 2596 & -1836 \\
\hline NW Europe & 840 & 1800 & -960 & 3064 & 5894 & -2830 \\
\hline Other Europe & 750 & 515 & 235 & 1793 & 1689 & 104 \\
\hline Oceania & \multirow{4}{*}{1413} & \multirow{4}{*}{575} & \multirow{4}{*}{838} & 455 & 129 & 326 \\
\hline Latin America & & & & 1531 & 595 & 936 \\
\hline Africa & & & & 680 & 307 & 373 \\
\hline Asia & & & & 1792 & 949 & 843 \\
\hline \multirow[t]{3}{*}{ Total } & 3720 & 4582 & -862 & 12176 & 13701 & -1525 \\
\hline & \multicolumn{6}{|c|}{ Manufactures } \\
\hline & \multicolumn{3}{|c|}{$1876-80$} & \multicolumn{3}{|c|}{1913} \\
\hline Region & Exports & Imports & Balance & Exports & Imports & Balance \\
\hline USA and Canada & 100 & 190 & -90 & 734 & 891 & -157 \\
\hline UK & 865 & 225 & 640 & 1751 & 601 & 1150 \\
\hline NW Europe & $1080^{\circ}$ & 450 & 630 & 3318 & 1795 & 1523 \\
\hline Other Europe & 210 & 330 & -120 & 578 & 1133 & -555 \\
\hline Oceania & \multirow{4}{*}{35} & \multirow{4}{*}{1285} & \multirow{4}{*}{-1250} & 9 & 370 & -361 \\
\hline Latin America & & & & 51 & 879 & -828 \\
\hline Africa & & & & 26 & 451 & -425 \\
\hline Asia & & & & 461 & 1247 & -786 \\
\hline Total & 2290 & 2480 & -190 & 6928 & 7367 & -439 \\
\hline
\end{tabular}

Source: P. Lamartine Yates (1959). Note that world trade does not balance due to unrecorded trade. 
Table 5. Average tariffs on manufactured goods, selected countries, 1913-1998

\begin{tabular}{lccccc}
\hline & 1913 & 1931 & 1950 & 1980 & $1998 / 99$ \\
\hline Austria & 18 & 24 & 18 & 14.6 & NA \\
Belgium & 9 & 14 & 11 & NA & NA \\
Denmark & 14 & - & 3 & NA & NA \\
France & 20 & 30 & 18 & NA & NA \\
Germany & 13 & 21 & 26 & NA & NA \\
Italy & 18 & 46 & 25 & NA & NA \\
Netherlands & 4 & -- & 11 & NA & NA \\
Spain & 41 & 63 & -- & 8.3 & NA \\
Sweden & 20 & 21 & 9 & 6.2 & NA \\
UK & 0 & -- & 23 & NA & NA \\
EU & NA & NA & NA & 8.3 & 4.1 \\
Russia & 84 & $* *$ & $* *$ & $* *$ & $13.4^{\mathrm{a}}$ \\
Switzerland & 9 & 19 & -- & 3.3 & $3.2^{\mathrm{b}}$ \\
Australia & 16 & -- & -- & -- & 6 \\
Canada & 26 & -- & -- & -- & 4.9 \\
Japan & $25-30$ & -- & -- & 9.9 & 5.5 \\
New Zealand & $15-20$ & -- & -- & -- & 4.4 \\
USA & 44 & 48 & 14 & 7 & 4.5 \\
Argentina & 28 & -- & -- & -- & 14 \\
Brazil & $50-70$ & -- & -- & -- & 15.2 \\
Colombia & $40-60$ & -- & -- & -- & 11.4 \\
Mexico & $40-50$ & -- & -- & -- & 12.6 \\
China & $4-5$ & -- & -- & -- & 17.4 \\
India & approx. 5 & -- & -- & -- & 34.2 \\
Iran & $3-4$ & -- & -- & -- & -- \\
Thailand & $2-3$ & -- & -- & -- & $47.2^{\mathrm{c}}$ \\
Turkey & $5-10$ & -- & -- & -- & 0.25 \\
\hline & & & & &
\end{tabular}

Sources: Bairoch $(1989 ; 1993)$; World Development Indicators 2000.

Notes: NA $=$ not applicable; $-=$ not available; $* *$ refers to the fact that the USSR ran such a restrictive trade policy that average tariffs were irrelevant; ${ }^{a}=1997 ;{ }^{b}=1996 ;{ }^{c}=1993$. 
Table 6. Average tariffs on manufactured goods, DCs, 1980-1993

\begin{tabular}{lcccc}
\hline Region & $1980-83$ & $1984-87$ & $1988-90$ & $1991-93$ \\
\hline Latin America and the Caribbean & 23.6 & 25.1 & 22.7 & 12.5 \\
East Asia & 21.6 & 18.1 & 18 & 17.1 \\
Sub-Saharan Africa & 32.8 & 23.5 & 22.5 & -- \\
\hline
\end{tabular}

Source: Rodrik (1999). 
Table 7. Composition of trade by region

\begin{tabular}{|c|c|c|c|c|c|c|c|c|c|}
\hline & \multicolumn{6}{|c|}{ Percent of merchandise exports } & \multicolumn{3}{|c|}{ Percent of total exports } \\
\hline & (1) & (2) & (3) & (4) & (5) & (6) & (7) & (8) & (9) \\
\hline Region & Food & $\begin{array}{l}\text { Ag. Raw } \\
\text { materials }\end{array}$ & Fuels & $\begin{array}{c}\text { Ores and } \\
\text { metals }\end{array}$ & Primary & Manufactures & Primary & Manufactures & Services \\
\hline East Asia and Pacific & 7 & 2 & 5 & 2 & 16 & 81 & 14 & 73 & 13 \\
\hline Europe and Central Asia & 6 & 3 & 20 & 7 & 36 & 56 & 31 & 48 & 21 \\
\hline Latin America and Carib. & 24 & 3 & 17 & 6 & 50 & 51 & 44 & 44 & 12 \\
\hline Middle East and N. Africa & 4 & 1 & 73 & 1 & 79 & 21 & 67 & 18 & 15 \\
\hline South Asia & 16 & 2 & 0 & 2 & 20 & 79 & 16 & 63 & 21 \\
\hline Sub-Saharan Africa & 15 & 4 & 29 & 14 & 62 & 39 & 55 & 35 & 11 \\
\hline High Income & 7 & 2 & 3 & 2 & 14 & 82 & 12 & 68 & 20 \\
\hline \multirow[t]{2}{*}{ World } & 8 & 2 & 5 & 3 & 18 & 82 & 15 & 66 & 19 \\
\hline & \multicolumn{6}{|c|}{$\begin{array}{l}\text { Percent of merchandise imports } \\
\end{array}$} & \multicolumn{3}{|c|}{ Percent of total imports } \\
\hline$\overline{\text { Region }}$ & Food & $\begin{array}{l}\text { Ag. Raw } \\
\text { materials }\end{array}$ & Fuels & $\begin{array}{c}\text { Ores and } \\
\text { metals }\end{array}$ & Primary & Manufactures & Primary & Manufactures & Services \\
\hline East Asia and Pacific & 5 & 3 & 10 & 5 & 23 & 74 & 19 & 63 & 18 \\
\hline Europe and Central Asia & 10 & 2 & 7 & 3 & 22 & 67 & 21 & 63 & 16 \\
\hline $\begin{array}{l}\text { Latin America and Carib. } \\
\text { Middle East and N. Africa }\end{array}$ & 9 & 2 & 7 & 2 & 20 & 80 & 17 & 69 & 14 \\
\hline South Asia & 12 & 4 & 18 & 5 & 39 & 56 & 33 & 47 & 21 \\
\hline Sub-Saharan Africa & 11 & 2 & 10 & 2 & 25 & 71 & 22 & 63 & 15 \\
\hline High Income & 8 & 2 & 7 & 3 & 20 & 77 & 17 & 64 & 19 \\
\hline World & 8 & 2 & 7 & 3 & 20 & 76 & 17 & 65 & 18 \\
\hline
\end{tabular}

Source: World Development Indicators 2001. Note: the entry in column (5) is the sum of columns (1) through (4). The sum of primary and manufactured trade in columns (5) and (6) is less than 100 because of unclassified trade. The data in column (9) are for commercial service exports only. 'Total' exports in columns (7) though (9) equals total merchandise exports plus commercial service exports. Columns (7) and (8) are calculated by assuming that total merchandise exports are allocated between the two categories in the same proportion as the figures in columns (5) and (6). 
Figure 1. European pepper prices

Deflated, $1505=100$

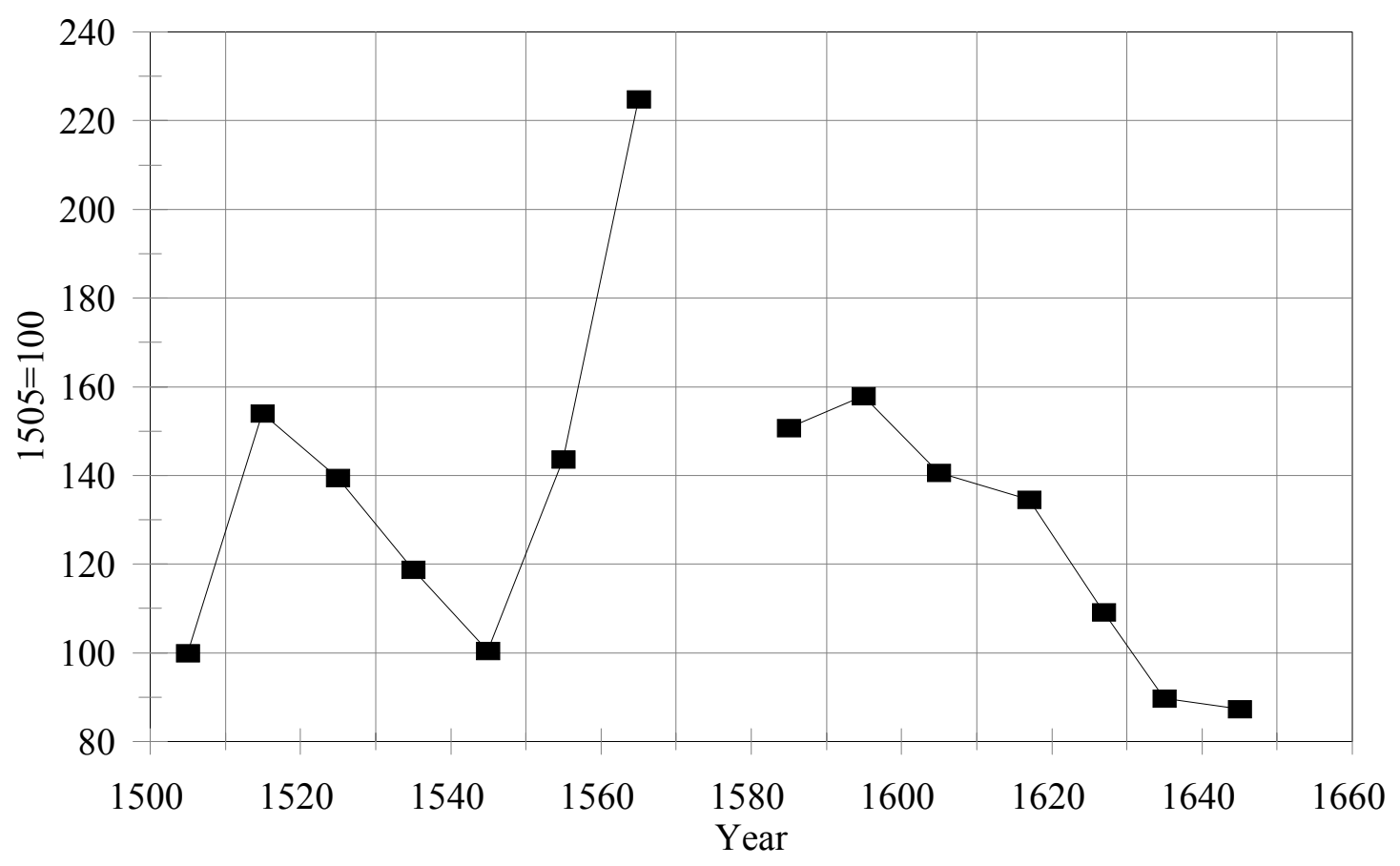


Figure 2. Spice and coffee markups:

Amsterdam vs. Southeast Asia 1580-1939

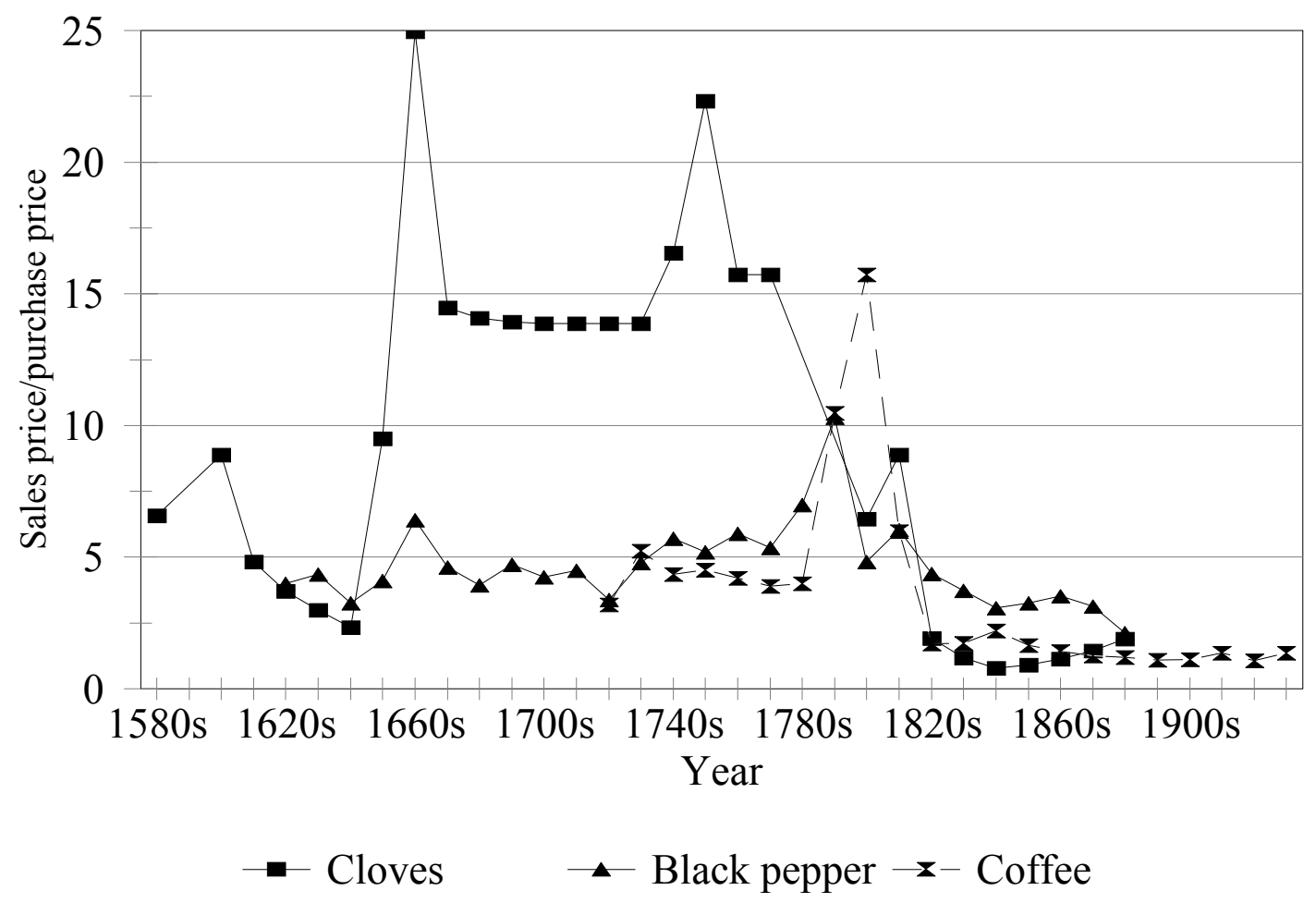


Figure 3. Asian textile trade markups

1664-1759

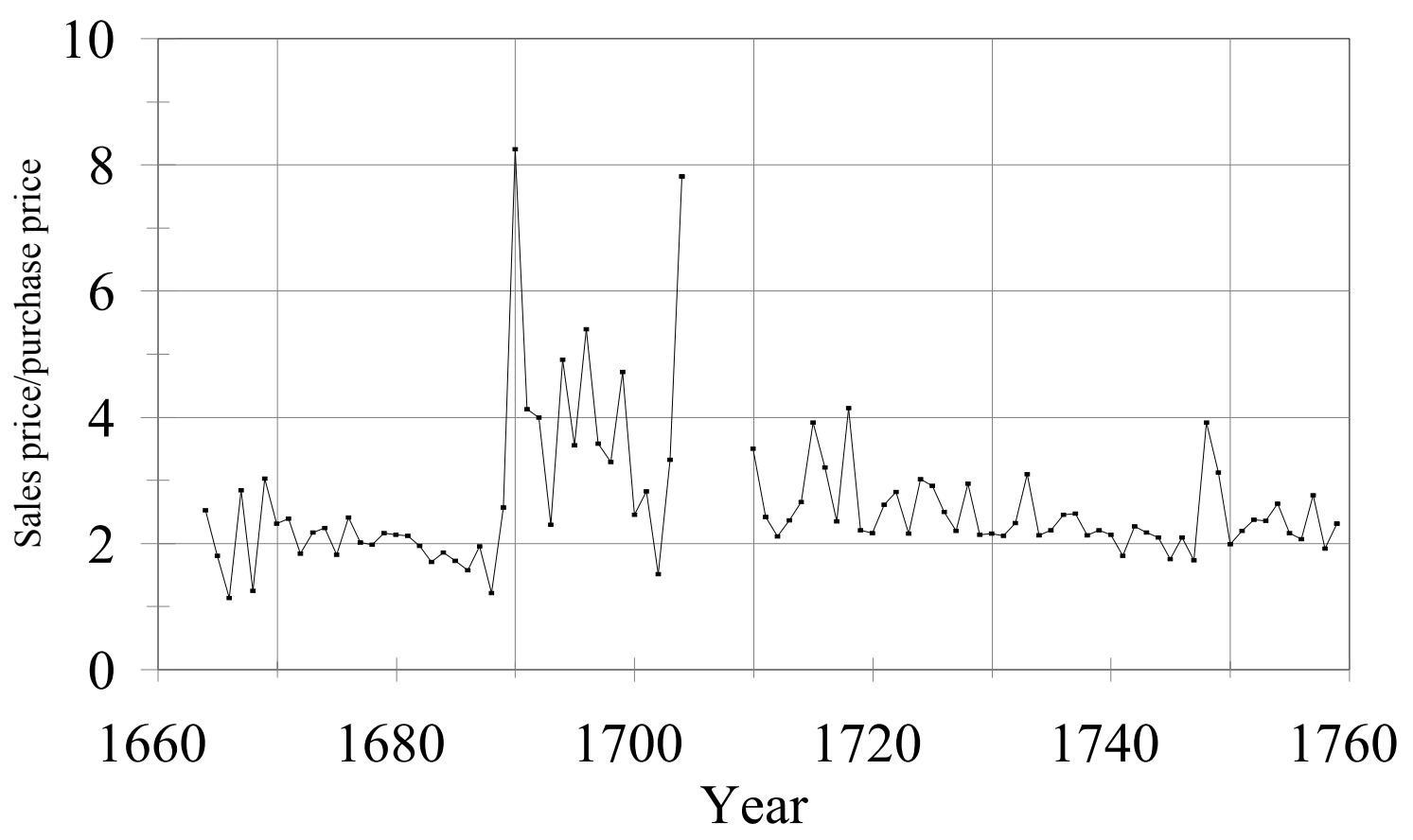


Figure 4. Deflated freight rates

$1869-1914(1869=100)$

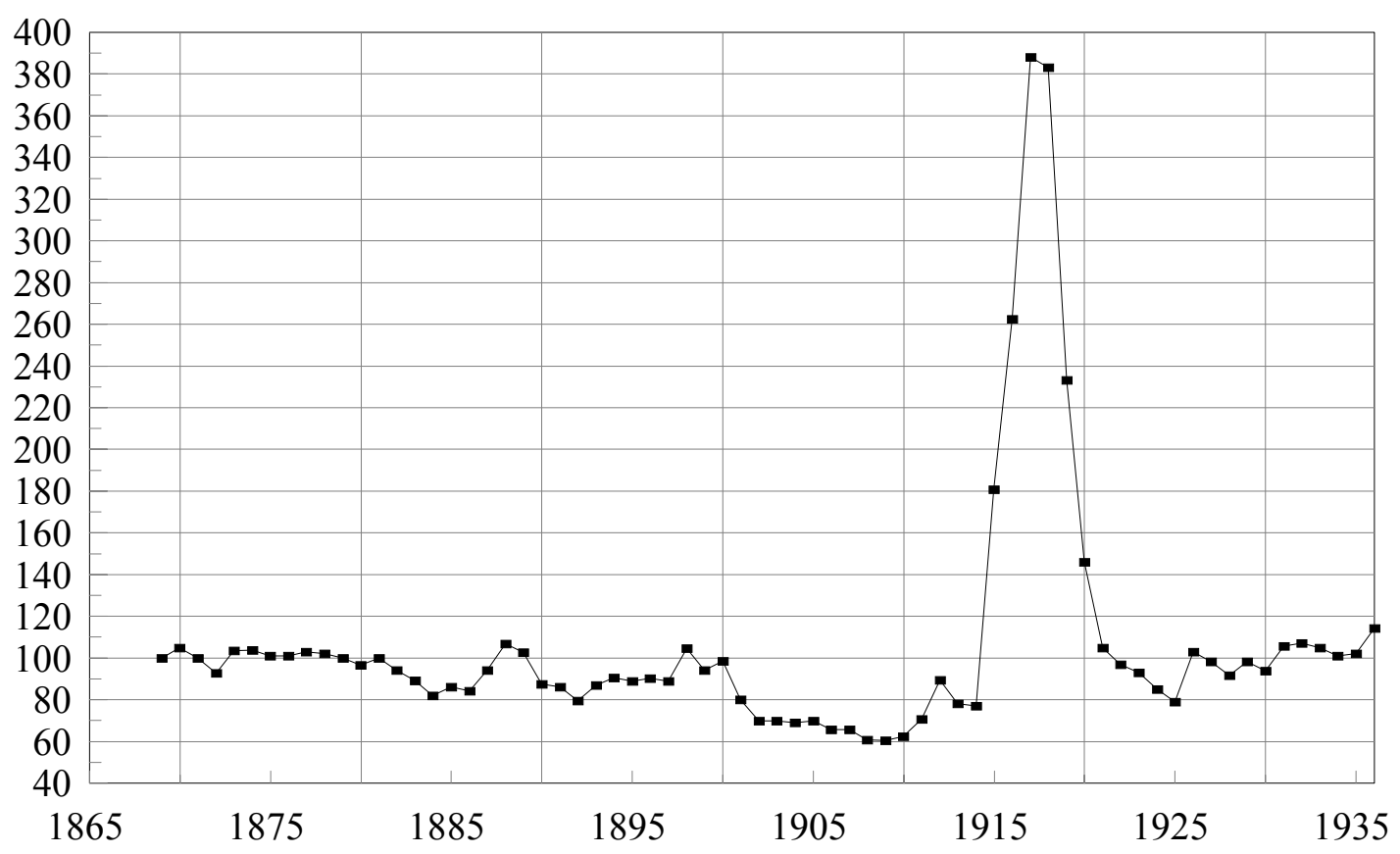


Figure 5. Sachs-Warner indicator

Fraction in each region open

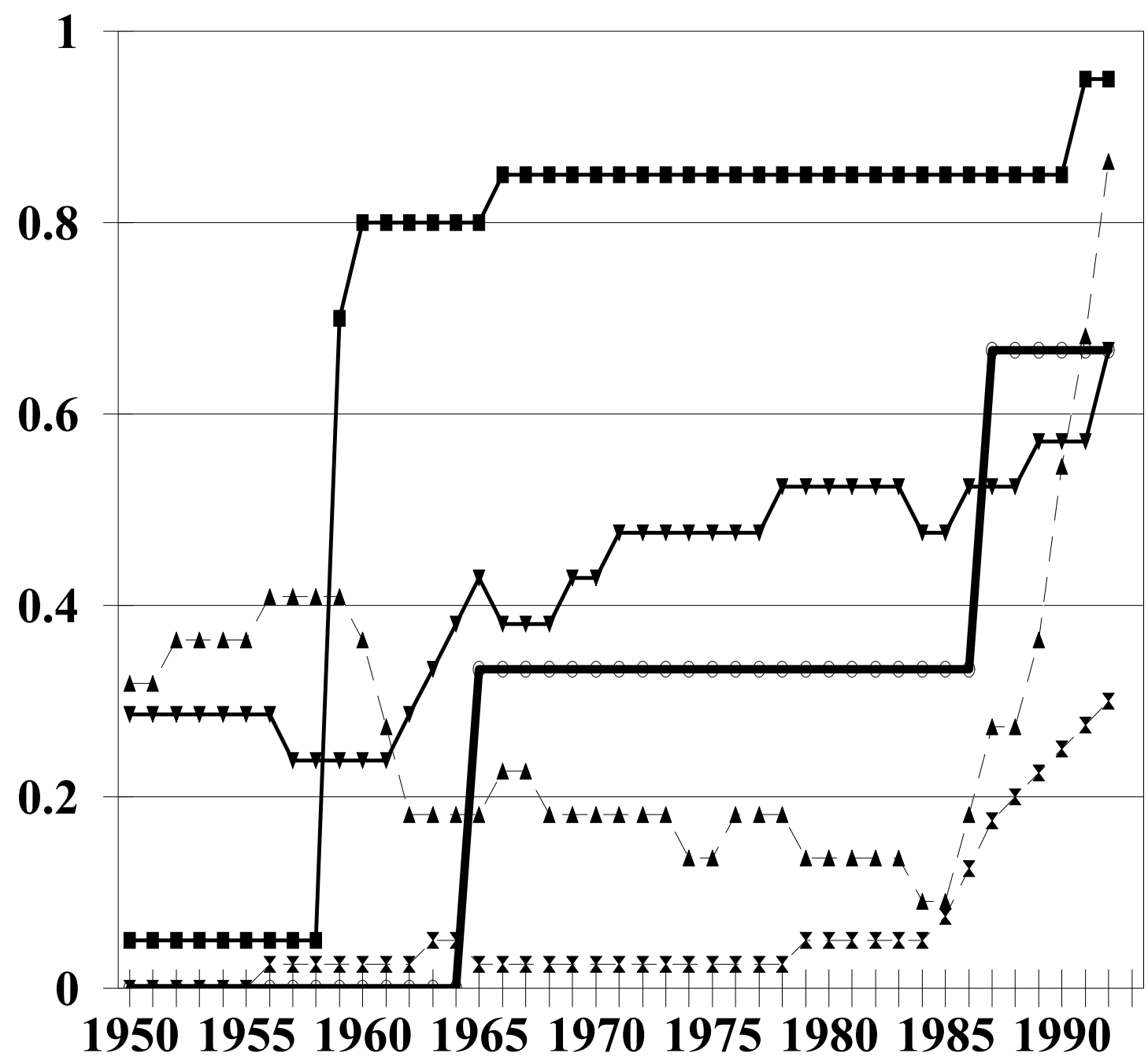

$$
\begin{aligned}
& \rightarrow-\text { AFRICA } \rightarrow-\text { LAC } \\
& \rightarrow \text { ASIA } \rightarrow \text { EUROPE } \\
& \rightarrow \text { SOUTH PACIFIC }
\end{aligned}
$$

